\title{
FUMBLING TOWARDS COHERENCE: THE SLOW EVOLUTION OF EQUALITY AND ANTI- DISCRIMINATION LAW IN BRITAIN
}

\section{Colm O'Cinneide, Lecturer in Law, Faculty of Laws, University College London}

\section{Introduction}

McCrudden has suggested that it is difficult to describe the scope of equality and anti-discrimination principles applicable in English public law, as:

"there is no one legal meaning of equality or discrimination applicable in the different circumstances. . . there is no consistency in the circumstances in which weaker or stronger conceptions of equality and discrimination currently apply ... . equality in English public law is . . . essentially pluralistic in its sources, in its origins, in its meanings, in its application, and in its functions."

This analysis is entirely accurate, except that the use of the term "pluralistic" is a little generous: "fragmented", "disjointed" or "piecemeal" could also serve. This same uncertainty exists in Scotland and Wales, albeit that the devolved administrations appear to share a commitment to substantive equality approaches that is not necessarily reflected throughout England (see the discussion on mainstreaming below). ${ }^{2}$

Due to this lack of consensus as to underlying principles, the development of equality and anti-discrimination law in Britain has taken place in fits and starts. ${ }^{3}$ When change occurs, it often tends to be reactive in nature. ${ }^{4}$ Legislation and new policies are usually introduced in response to events, or to fill a sufficiently embarrassing gap in the legislation, or to comply with the requirements of EC law. This disjointed approach has persisted since the introduction of the earliest forms of anti-discrimination legislation in the

1 C. McCrudden, "Equality and Non-Discrimination", Chap.11 in D. Feldman, English Public Law (2004), para.11.02, at p.582.

2 The enactment of equality and anti-discrimination legislation remains a function reserved to Westminster, but considerable room does exist for both devolved administrations to develop equal opportunities approaches in how they exercise their devolved functions and powers. As discussed below, the Welsh Assembly is under a positive duty to promote equality of opportunity, as is the Greater London Authority (GLA), which is perhaps the body at the forefront of the development of new equality strategies. See GLA, Into the Mainstream: Equalities Within the Greater London Authority (2003) for a comprehensive summary of the GLA's equalities initiatives.

3 The evolution of equality and anti-discrimination law in Northern Ireland has followed a very different trajectory.

4 Perhaps the major exception to this general trend was the introduction of comprehensive sex and race discrimination legislation in the mid 1970s, predating similar steps in some other European countries by several decades. See A. Lester, "Discrimination: What Can Lawyers Learn From History" [1994] Public Law 224. 
1960s, and has produced a complex hybrid of equality principles embedded in a patchwork quilt of anti-discrimination legislation and case-law. ${ }^{5}$ The "variable geometry" of EU and UK anti-discrimination legislation means that different levels of protection exist across the different grounds of prohibited discrimination. Multiple or intersectional forms of discrimination do not fit comfortably into this framework. ${ }^{6}$

Since 1995, anti-discrimination protection has been extended to the "new" grounds of disability, sexual orientation, religion and (imminently) age, while the scope of existing protection in the areas of race and gender has been extended. This has been paralleled by considerable shifts in judicial approaches to equality issues, with some development of common law equality principles and a move towards the purposive interpretation of antidiscrimination legislation. These developments have been accompanied by the introduction of positive equality duties, attempts to introduce mainstreaming initiatives, the coming into force of the Human Rights Act and the establishment of a single Commission for Equality and Human Rights.

This transformation of British equality law has not been immune from its recurring defects, exemplified in particular by the piecemeal, stumbling and reactive manner in which these reforms have been introduced. Nevertheless, it can be argued that the cumulative effect of these changes has been to establish the bare bones of a coherent framework of equality and antidiscrimination law. However, the conceptual uncertainties noted by McCrudden remain. Fundamental questions as to how this evolving legal framework should be further developed remain unresolved.

Part One of this article will examine the underlying conceptual uncertainties that continue to afflict British equality law and policy. Part Two will assess the scope and effectiveness of the recent extension of anti-discrimination legislation in Britain, while Part Three will outline how equality and antidiscrimination norms are becoming "constitutionalised" in British public law. Part Four will then look at attempts to require public and private authorities to take proactive action to eliminate patterns of inequality, and how conceptual uncertainties persist as to the appropriate scope and direction to be given to "transformative" equality measures. British equality law is fumbling towards greater coherence, consistency and clarity, but real obstacles to achieving full coherence persist.

5 A similar complex hybrid of equality norms and levels of protection exists in EC law, which contributes in its turn to the complexity of British law: see A. Morris, "Constitutionalising Equality in the European Union: Tolerance and Hierarchies" (2005) 8(1) International Journal of Discrimination and the Law 33-52; M. Bell, "The Right to Equality and Non-Discrimination", in T. Hervey and J. Kenner (eds.), Economic and Social Rights under the EU Charter of Fundamental Rights. A Legal Perspective (2003), 91-110; M. Bell, Anti-discrimination Law and the European Union (2002); M. Bell and L. Waddington, "Reflecting on Inequalities in European Equality Law" (2003) 28 European Law Review 349-369.

6 See S. Hannett, "Equality at the Intersections: The Legislative and Judicial Failure to Tackle Multiple Discrimination" [2003] 23(1) OJLS 65-86. 


\section{Part One: Attempting to Achieve Conceptual Coherence in Equality and Anti-Discrimination Law}

Much academic literature has been generated in an attempt to formulate a clear conceptual basis for equality and anti-discrimination law. This desire to achieve some sort of conceptual coherence stems from the notoriously fuzzy nature of the concept of "equality" itself, and the often conflicting alternative accounts of what constitutes fidelity to this slippery and elusive value. ${ }^{7}$ McCrudden has suggested that current European and British legal approaches attempt to balance and combine at least five different concepts of equality. ${ }^{8}$ Fredman suggests that equality law and policy are based upon an often confused combination of different models of equality - "formal equality", that is, equality viewed as sameness of treatment of those in similar situations, "equality of opportunity", that is equality viewed as creating the necessary conditions to ensure a fair and equal starting point for all, and "equality of outcome", that aims to eliminate disadvantages faced by particular social groups. While recognising that elements of all three approaches are deeply embedded in contemporary law and policy, she advocates a greater focus on "equality of outcome" and "substantive equality" approaches, which would make the removal of obstacles faced by disadvantaged groups to full participation in society the main guiding principle of equality law. ${ }^{9}$

Other commentators have argued for a radical move away from any attempt to rely upon the concept of equality to serve as a firm normative base for equality and anti-discrimination law. Westen famously described equality as an empty concept, devoid of any real substance. ${ }^{10}$ Raz has also been sceptical of the value of equality as a meaningful normative concept: while the language of equality may have value from a rhetorical point of view, justifications for anti-discrimination norms must be found elsewhere. ${ }^{11}$ Matt Cavanagh has recently suggested that a defence of equality of opportunity as a moral good cannot be sustained, ${ }^{12}$ while Tim Macklem has argued that equality of opportunity is not a coherent principle in its own right, but simply a "placeholder for other principles, the most familiar of which today is nondiscrimination". ${ }^{13}$

7 See N. Bamforth, "Conceptions of Anti-discrimination Law" (2004) 24(4) OJLS 693.

8 McCrudden identifies these principles as equality as "rationality", equality as protecting "prized public goods", equality as preventing "status harms" arising from discrimination on the basis of particular grounds, equality as "proactive promotion of equality of opportunity between particular groups", and equality as ensuring the "participation" of excluded groups. See both McCrudden, "Equality and Non-Discrimination", paras.11.04-11.07, pp.582-583, and by the same author, "Theorising European Law", in C. Costello and E. Barry (eds.) Equality in Diversity: The New Equality Directives (2003) 1.

9 See Fredman, Discrimination Law (2001), pp.21-22. See also S. Fredman, The Future of Equality in Britain (2003).

10 P. Westen, "The Empty Idea of Equality" (1985) 95 Harv L. R. 537

11 J. Raz, The Morality of Freedom (1986), Ch. 9.

12 M. Cavanagh, Against Equality of Opportunity (2002)

13 T. Macklem, "Equality and Opportunity: Reconciling the Irreconcilable" (2005) 68(6) MLR 1016-1033, 1033. Similar arguments that anti-discrimination norms in 
In arguing for a jettisoning of reliance upon equality as a guiding principle, many of these critiques have suggested that equality and anti-discrimination legal norms should instead be regarded as designed to remove obstacles to the enjoyment of basic human entitlements, to combat attempts to deny human dignity, or to express contempt towards particular groups. ${ }^{14}$ Conceptualising the normative basis for anti-discrimination norms in this way has its attractions. It can explain why particular types of discrimination directed against particular social groups are singled-out for particularly intense forms of legal regulation and attract particular moral abhorrence. It also cuts through much of the confusion generated by the linking of equality and anti-discrimination law to fuzzy and contested concepts of equality. Eliminating disadvantage that constitutes a denial of dignity or basic entitlements can readily be shown to be more important than ensuring exact sameness of treatment for all. Therefore, this approach justifies placing less emphasis upon ensuring sameness of treatment, which Fredman suggests exercises a distorting effect upon the development and application of much of current British equality law and policy. ${ }^{15}$ The view that equality and antidiscrimination legal norms are firmly rooted in a concern for the preservation of human dignity has been adopted with particular enthusiasm by the Canadian Supreme Court. ${ }^{16}$

However, as Moreau has noted, equality and anti-discrimination legal norms address a complex variety of different types of harm or demeaning treatment. ${ }^{17}$ Attempts to define a single underlying targeted wrong, such as attacks upon human "dignity", the expression of "contempt", group "stereotyping", the denial of autonomy or other basic human entitlements, and so on, tend to be either under-inclusive or excessively vague..$^{18}$ Equality

particular can and should be disentangled from the conceptual swamp of attempts to define equality of opportunity have been made by Eliza Holmes: see E. Holmes, "Anti-Discrimination Rights Without Equality" (2005) 68(2) MLR 175-194.

14 See N. Bamforth, "Conceptions of Anti-Discrimination Law", 713-715. Gardner has suggested that anti-discrimination law can be justified inter alia as designed to remove unjustified impediments to personal autonomy, and can serve as a redistributionist tool: see J. Gardner, "Liberals and Unlawful Discrimination" (1989) 9 OJLS 1. Many feminist theorists call for the breaking down of oppressive social practices which deny meaningful life opportunities to women, and are at best sceptical about any appeals to the language of "equality". See C. MacKinnon, "Sex Equality: On Difference and Domination", in Toward a Feminist Theory of the State (1989), 215. See also D. Réaume, "Comparing Theories of Sex Discrimination: The Role of Comparison" (2005) 25(3) OJLS 547-564, who suggests that feminists have been compelled to use the language of equality in the absence of other recognised forms of legal or political rhetoric to challenge gender-based forms of oppression and the denial of fundamental dignity. See also by the same author, "Discrimination and Dignity" (2004) Louisiana L. Rev 1.

15 See Fredman, Discrimination Law (2001).

16 See Laws v Canada (Minister for Employment and Immigration) [1999] 1 S.C.R. 497

17 S. Moreau, "The Wrongs of Unequal Treatment" (2004) 54(3) University of Toronto L. J. 291-326.

18 Ibid., 296-318. For example, Cavanagh's acceptance that discrimination is unjustified when it expresses "unwarranted contempt" can be given a very narrow ambit, or could extend to cover a very wide range of actions and social structures depending upon what is deemed to constitute an expression of unwarranted 
and anti-discrimination legal norms are designed to combat a complex set of different "wrongs", which take various forms across the different controlled grounds of discrimination and in different social contexts. The selection of which forms of discriminatory "wrongs" should be subject to legal regulation stems from social and political decisions that certain types of discrimination involve a denial of dignity by assuming the lesser worth of individual or group concerned, or subject particular groups to serious obstacles and extra burdens from which other groups are generally exempt. In other words, in calibrating which actions deserve regulation through equality and antidiscrimination law, there is usually some reference back to ideals of equality of respect and equal worth, even if these concepts are relatively inchoate. ${ }^{19}$ Normative appeals to concepts of equality are not so easy to disentangle from the conceptual framework of equality law.

This is particularly obvious when consideration is given to the role of the state. Denials of dignity or basic entitlements will often be generated by the state making distinctions between different social groups, or permitting the existence of such distinctions. This can take the form of variation in the legal rights that different groups are accorded, or in the extent to which the interests and needs of different groups are protected in legislation and public policy. It can also rise in the way that particular social groups are allowed to oppress other groups. If the state is responsible for such treatment, or does not attempt to prevent its continuance, then this can be conceptualised as a failure by the state to respect the dignity of all, to provide basic entitlements, or even to act rationally. ${ }^{20}$ However, in deciding whether a case exists for regulation via equality and anti-discrimination legal norms, and whether a social group has in fact been treated differently than another group, there is usually a need to recourse to the inchoate and uncertain set of concepts usually encapsulated within the term "equality of respect and concern", if only as instrumental tools of assessment. ${ }^{21}$

It is also essential to note that the basic perception that human dignity is offended by discriminatory treatment stems from a normative attachment to an ideal of the equality of status of human beings. Historically, many categories of humans were viewed as being of lesser status: for example, in certain cultures, it might be considered a legal and moral wrong to deny basic entitlements to slaves, but it was entirely permissible to treat them as

contempt. The same is true for attempts to root anti-discrimination norms in ideas of the infringement of human dignity, or denials of individual autonomy. See Cavanagh, Against Equality of Opportunity (2002).

19 Raz has suggested that greater equality as between different social groups is often a by-product of equality and anti-discrimination legal norms, not their underlying rationale: however, achieving this "by-product" is often a key element in defining which forms of intrusion upon human dignity are classed as illegitimate discrimination. Raz, The Morality of Freedom, at 228. Returning to the example of Cavanagh's concept of "unwarranted contempt" cited in the footnote above, defining what constitutes "unwarranted contempt" will inevitably involve a comparison of treatment between different groups.

20 See the argument in J. Stanton-Ife, "Should Equality Be a Constitutional Principle?" (2000) 11 (2) King's College LJ 133-52.

21 See the discussion in R. Dworkin, Sovereign Virtue: The Theory and Practice of Equality (2000), Chs. 2 \& 4. 
less than fully human. ${ }^{22}$ In contemporary conditions, there is a strong and growing attachment to the idea that human dignity is denied by such concepts of unequal status. Equality and anti-discrimination law may be structured around the prevention of certain types of denial of dignity: but its ultimate raison d'être is as a tool to help achieve some form of social transformation, as part of the unfolding logic of a commitment to an ideal of equality of status. ${ }^{23}$

Equality and anti-discrimination norms can therefore be seen as complex construct of different elements: they are designed to prevent certain types of denial of human dignity rather than to guarantee "equality of opportunity" per se, but their use is also directly or indirectly intended to alter social structures to secure greater equality of respect or status for disadvantaged groups. They are also often "packaged" within a wider range of measures directed towards the elimination or amelioration of group disadvantage: antidiscrimination legislation is regularly accompanied by alterations in police practice, housing and family policies, and other forms of provision of public services.

Hugh Collins has drawn attention to this close link between antidiscrimination legislation and the use of other social policy tools. He suggests that equality law is best viewed as part of an overall strategy of combating forms of social exclusion faced by particular disadvantaged groups. He therefore argues that British equality law and policy can be regarded as built around a central structuring principle of "social inclusion". ${ }^{24}$ The strength of this analysis is that it provides a coherent explanation for why anti-discrimination law prohibits certain types of harm inflicted upon specific "excluded" social groups. It also situates this legislation within a wider range of government initiatives and policy approaches that are closely concerned with addressing social exclusion. It captures current British government thinking on equality policies very well, in particular the new policy approaches being developed to address issues of "community cohesion". 25

However, the possible disadvantage of this "social inclusion" analysis as a conceptual framework is that it may not adequately capture the potential transformative effect of equality law. Equality and anti-discrimination legal norms are capable of not alone removing obstacles to social inclusion by particular groups, but also of transforming existing social norms that are discriminatory in nature and effect. This transformative dimension is perhaps more often an aspiration than a reality. However, it remains a

22 See the disturbing account of how female slaves could be ceremoniously denied an afterlife to benefit Viking lords, by means of a particular human sacrifice ritual involving rape, in T. Taylor, The Buried Soul: How Humans Invented Death (2002). The slave in this ritual was conceptualised as an entirely disposable commodity, with no status as an "equal" even in the most formal and rhetoric sense of this term.

23 I am grateful to Riz Mokal for helping me to clarify my thoughts on this point.

24 H. Collins, "Discrimination, Equality and Social Inclusion", (2003) 66(1) MLR 1643 .

25 See in particular Home Office, Improving Opportunity, Strengthening Society (2005) 
potential outcome, and a key element of what equality norms aspire to achieve.

The language of "social inclusion", with its connotations of inclusion within a fixed norm, may not adequately capture this transformative, even utopian, aspiration of equality law. ${ }^{26}$ Superficially successful inclusion within unjust or discriminatory social structures is possible, even though it may require previously excluded groups to suffer hidden costs and to conform to dominant norms. The integration of women in the workplace can be seen as a triumph of "social inclusion": however, the persistent failure of corporate culture to accommodate carer responsibilities, the burdens of pregnancy and alternative working methods continues to clash with the transformative ambitions of equality norms. ${ }^{27}$ In contrast, the advantage of Fredman's substantive equality approach is that it places the transformation of social structures front and centre in its account of what a coherent equality approach should aim to achieve. This account of equality norms is perhaps closer to their inherent aspirations and underpinning logic than the language of "social inclusion", even if it does not always reflect their often limited impact in practice.

However, even if the existence of this transformative dimension is accepted, substantial disagreements still exist as to which jurisprudential or philosophical theories best encapsulate and describe these aspirations. In particular, dispute exists as to the extent to which these transformative ambitions should be stretched. How far should legal regulation be utilised to alter existing practices, concepts of merit, and the freedom of action of individuals and corporations? Considerable disagreement also exists as to what extent should group differences be institutionalised within law and policy, and in particular to what extent should religious sensitivities, different beliefs, and differences between different ethnic groups be reflected in legislation, policy and state practice. In other words, two areas of stark and often passionate disagreement exist: how much "social engineering" should be conducted via equality and anti-discrimination law, and how much "group differentiation" should be institutionalised? These areas of disagreement are ultimately rooted in wider conceptual disputes as to the relationship between equality, liberty, autonomy and other values, as well as to the appropriate role of the state vis-à-vis different forms of group identity.

Nevertheless, in mainstream British legal and political debate, it can now be argued that considerable agreement exists as to what a coherent framework of equality and anti-discrimination law should look like. ${ }^{28}$ There is widespread acceptance that equality and anti-discrimination law should

26 Collins's main ambition in his thoughtful analysis appears to be to describe the existing theoretical basis for much of contemporary equality law and policy, without necessarily engaging in a normative analysis of the merits and legitimacy of "social inclusion" as an underlying principle, or how "transformative" this approach could prove to be.

27 For the latest statistical evidence of this, see T. Hogarth and P. Elias, Pregnancy Discrimination at Work: Modelling the Costs, Equal Opportunities Commisison Working Paper Series No. 39 (2005)

28 This is evidenced by the relatively uncontroversial nature of recent legislative and judicial developments discussed later in this article. 
prohibit the illegitimate use of certain types of classification; apply not just horizontally between private entities but also to vertical relationships between disadvantaged groups and the state; and be capable of having some transformative effect, by making possible challenges to social norms that unfairly exclude or disadvantage particular social groups. There is also an underlying acceptance that any coherent framework of equality and antidiscrimination law should also reflect the Fullerian virtues of rationality, consistency and clarity. ${ }^{29}$

However, uncertainty persists about which conceptual account best describes and justifies the existence of this legal framework. Serious disagreement also exists as to the appropriate limits to its transformative ambitions and scope of application. Therefore, in line with Sunstein's description of an "under-theorised concept", it can be argued that substantial agreement exists on the essential contours of an effective equality law framework. This makes it possible to establish this basic framework by legislative and judicial reform, and for it to be operable within the British legal system. However, ultimate consensus on its foundational theories and ultimate guiding principles does not exist. ${ }^{30}$

Recent developments in British equality law reflect this combination of agreement about mid-level operating principles, and strong disagreement about foundational and guiding principles. New legislation has extended the scope of equality and anti-discrimination legal norms. It has cured some obvious inconsistencies and defects. There is a gradual move towards the establishment of a consistent and comprehensive basic floor of legal protection against the major forms of discriminatory behaviour. There is also an acceptance of the role of the state in perpetuating discriminatory patterns. Equality law is increasingly capable of being applied not just horizontal relationships, but also to vertical relationships between governance structures and the governed. As Bamforth has argued, it is necessary to adopt an "integrated constitutional conception" of equality law, and this is slowly emerging in Britain. ${ }^{31}$ There has even been a greater recognition of the transformative aspirations inherent in concepts of equality, and a willingness to introduce some legal mechanisms that attempt to transform policies and practices that may have discriminatory effect.

However, serious conceptual debates persist. Their lack of resolution continues to block the evolution of a fully coherent equality law. In the absence of a comprehensive guiding vision, uniformity of approach and incremental tinkering often replaces clarity of principle, and incoherence persists. This pattern is replicated across the various elements of British equality law. In particular, this pattern can be seen in the evolution of antidiscrimination legislation.

29 See L. Fuller, The Morality of the Law (1964)

30 C. Sunstein, "Incompletely Theorized Agreements" (1995) 108 Harv L. Rev 1733, 1739-40. Sunstein divides such agreements into several different categories: equality and anti-discrimination law in Britain fits into his second category.

31 See N. Bamforth, "Conceptions of Anti-Discrimination Law", 701. 


\section{Part Two: The Slow Shuffle Towards Legislative Reform}

Following the initial introduction of race relations legislation in the 1960s, and the enactment of the Equal Pay Act 1970, comprehensive race and sex discrimination legislation was introduced in Britain in the mid 1970s. The scope of this legislation was gradually clarified by judicial interpretation and the occasional minor legislative intervention, often driven in the context of gender by EC legislation. ${ }^{32}$ This has resulted in the establishment of a relatively comprehensive framework of legislative protection against direct and indirect forms of race and sex discrimination in employment, occupation, education, and access to goods and services. ${ }^{33}$ This legislation is now often seen as a part of the legal rights of UK citizens and has had considerable symbolic, educative and deterrent impact. ${ }^{34}$ However, the scope of protection offered by this legislation was limited: other grounds of unfair treatment remained outside its scope. Unsuccessful attempts were made to extend the race and sex discrimination legislation to cover discrimination on the grounds of sexual orientation, religious belief and age. ${ }^{35}$

However, recent years have seen a considerable expansion of the scope of anti-discrimination legislation. This has been largely driven by the EU Framework Equality Directive 2000, which required the UK to introduce inter alia legislation prohibiting discrimination in employment and occupation on the grounds of religious belief and sexual orientation by the end of 2003, and to do the same for discrimination on the grounds of age by the end of 2006. ${ }^{36}$ The Employment Equality (Sexual Orientation) and Employment Equality (Religion or Belief) Regulations 2003 have been

32 See e.g. the Sex Discrimination (Indirect Discrimination and Burden of Proof) Regulations 2001, S.I. 2660, implementing the Burden of Proof Directive 97/80. For an unusual example of legislative reform introduced without the intervention of EC legislation, see the Race Relations (Remedies) Act 1994, which removed the upper cap on damages for race discrimination.

33 Without the propulsion provided by the ECJ and the EC Equal Treatment and Equal Pay Directives, it is questionable whether the current levels of protection would have been attained. The jurisprudence of the European Court of Justice (ECJ) has played a very significant influence upon the interpretation of the Sex Discrimination and Equal Pay Acts, and indirectly upon the application of the race relations legislation. See A. Lester, "Discrimination: What Lawyers Can Learn From History" (1994) Public Law 224-237, 229-235.

34 See B. Hepple, M. Coussey, and T. Choudhury, Equality: A New Framework, Report of the Independent Review of the Enforcement of UK Anti-Discrimination Legislation (Oxford: Hart, 2000), para.1.33 (hereafter the "Hepple Report").

35 For an attempt to extend the protection of sex discrimination legislation to discrimination on the grounds of sexual orientation, see McDonald v Advocate General for Scotland [2003] UKHL 34. For similarly unsuccessful attempts to extend the race relations legislation to cover discrimination based upon religious belief, see J.H. Walker v Hussain [1996] IRLR 11 (EAT), Crown Suppliers (PSA) v Dawkins [1993] IRLR 284. For an unsuccessful attempt to use the sex discrimination legislation to challenge retirement ages, see Rutherford v SS TI [2004] EWCA Civ. 1186, CA. In Northern Ireland, on the other hand, discrimination on the grounds of religious belief and political opinion has been prohibited since 1976.

36 EU Council Directive 2000/78 establishing a general framework for equal treatment in employment and occupation, O.J. Series L 303/16. 
introduced to implement this obligation. ${ }^{37}$ The draft Age Regulations have been published for consultation and are expected to become law in their final form by October 2006. ${ }^{38}$ These regulations adopt the same basic format and approach as the existing race and sex discrimination legislation, as required by the Directive. ${ }^{39}$ However, their scope is confined to that of the Directive, i.e. employment and occupation. Discrimination on these grounds in access to goods and services, no matter how malignant or overt, is not covered. ${ }^{40}$

This limited scope was justified by the UK government on the basis that extending the new legislation further than the scope of the Directive would generate complex and difficult issues. ${ }^{41}$ This caution is a persistent element of UK government responses to pressure to extend anti-discrimination legislation, and is a less than golden thread that has run through the equality policies of both Conservative and Labour governments since the 1980s. ${ }^{42}$ This timidity stems partially from a desire not to be seen to "overburden" private employers and service providers, and a reluctance to offend certain sectors of public opinion by legislating on matters of some controversy. It is also compounded by neo-liberal preferences for private solutions and government non-intervention, and is largely responsible for the piecemeal, reactive and ad hoc nature of anti-discrimination law in Britain. ${ }^{43}$ Legislation is introduced in response to the requirements of EU law or where sufficient political pressure builds up for change in a specific area, rather than as part of a coherent scheme based upon the recognition of the structural and rooted nature of many inequalities. ${ }^{44}$ These tendencies reflect a strong reluctance to recognise and give effect to the transformative dimension of equality norms, and a hesitancy to curtail individual and corporate autonomy: anti-discrimination legislation has been essentially seen as a tool of last resort to reduce the occurrence of certain types of serious harms, rather than

37 See M. Bell, "A Patchwork of Protection: The New Anti-Discrimination Law Framework" (2004) 67(3) MLR 465-477, especially 467-475; L.Vickers, "Freedom of Religion and the Workplace: The Draft Employment Equality (Religion or Belief) Regulations 2003' (2003) 32 ILJ 23, 27.

38 For the draft age regulations, see UK Department of Trade and Industry, Coming of Age (2005).

39 A. Lester, "New European Equality Measures", (2000) Public Law 642

40 The changes made to the race relations legislation by the Race Relations Act 1976 (Amendment) Regulations 2003 were also confined to the minimum steps necessary to satisfy the requirements of the Race Equality Directive. This ensured that a new series of complex distinctions and varying levels of protection have been introduced into the formerly homogenous race relations legislation: see $\mathbf{M}$. Bell, "A Patchwork of Protection", at pp.466-7.

41 See the discussion in Department of Trade and Industry (DTI), Towards Equality and Diversity (2001).

42 The same set of explanations was also forthcoming for the preference of the UK government for combating age discrimination via a voluntary Code of Practice (subsequently acknowledged to be ineffective), rather than through enforceable age discrimination legislation. See Department of Works and Pensions, Evaluation of Practice on Age Diversity in Employment (2001).

43 Mark Bell has described the state of British anti-discrimination law as a "patchwork of protection": M. Bell, "A Patchwork of Protection", 465.

44 In the author's experience, attempting to teach British anti-discrimination law inevitably leaves students aghast at its incoherence and complexity. 
a fundamental building block of a society founded on concepts of dignity and equal status.

\section{The Pressure for Convergence}

However, the complex and inconsistent structure of British antidiscrimination legislation is proving to be unsustainable. The existence of complex and confusing distinctions between different equality grounds generates claims by activist groups for protection against discrimination to be "levelled up" across the grounds. Multiple or overlapping forms of discrimination can become very difficult to handle. ${ }^{45}$ Varying levels of protection encourage complex litigation. Conceptually, many of the distinctions between grounds are extremely difficult to justify, and this produces strong pressure for convergence of protection across the equality grounds.

The UK government is extending protection in Britain against religious discrimination to goods and services, education and other forms of service provision in the Equality Act 2006. While it initially relied yet again upon the principle of "unripe time" to postpone consideration of taking equivalent steps for age and sexual orientation, ${ }^{46}$ pressure for convergence has provoked a change of heart, and similar protection is now to be extended to sexual orientation. It may only be a matter of time before protection against age discrimination is similarly extended: experience from the Republic of Ireland has shown that this is possible. ${ }^{47}$

The same gradual process of levelling-up has occurred in the context of disability discrimination. The Disability Discrimination Act (DDA) 1995 fell short of the race and sex discrimination legislation in several important respects. In particular, its definition of disability was problematic, its provisions were often unwieldy and lacked clarity, and it did not apply to education and other areas covered by the race and sex discrimination legislation. It also failed to provide for the establishment of a Disability Rights Commission (DRC) to play a similar promotion and enforcement role to the Commission for Racial Equality (CRE) and Equal Opportunities Commission (EOC). ${ }^{48}$

The inevitable demands for a convergence of protection resulted in the introduction of legislation establishing the DRC in 1999 and extending

45 As the extent of protection available to a claimant may vary considerably depending upon which grounds are identified as the "source" of the treatment in question, pressure exists upon courts and tribunals to compartmentalise a complaint within one particular ground, rather than taking an approach that recognises how different forms of discrimination may overlap and reinforce each other. See S. Hannett, "Equality at the Intersections: The Legislative and Judicial Failure to Tackle Multiple Discrimination", 65-86.

46 See F. Cornford, Microcosmographia Academica: Being a Guide for the Young Politician (1908), Ch. VII, for the classic exposition of this valuable political doctrine.

47 For the Irish legislation, see C. O'Cinneide, “Age Discrimination and Irish Equality Law', in E. O'Dell (ed.) Older People in Modern Ireland: Essays on Law and Policy (2006).

48 C. Gooding, "The Disability Discrimination Act 1995: An Overview", in J. Cooper, Law, Rights and Disability (2000) 139-163, 139. 
protection against disability discrimination to educational institutions in $2000 .^{49}$ The legislation has subsequently also seen further modification, to ensure compliance with the disability requirements of the Framework Equality Directives, and to close some of other gaps left by the 1995 legislation. ${ }^{50}$ Problems remain, but the pressure for convergence has generated considerable changes since 1995 .

Therefore the patchwork structure of existing anti-discrimination legislation generates pressure in favour of "levelling-up" of protection across the different equality grounds. The aspirations towards fairness, consistency and adequate protection that are inherent in anti-discrimination norms rest uneasily with the inconsistency and lack of clarity of the current legislative provisions. This is not to say that there should necessarily be complete equivalence of protection across the different grounds: there may be very good grounds for having differing provisions, especially when it comes to issues linked to religious belief. However, any distinctions in the scope of protection across the grounds should be justified by reference to tangible moral and social considerations, rather than being the product of legislative inertia. There is a need for comprehensive equality legislation to level up levels of protection across the different equality grounds where appropriate, and to ensure greater clarity and consistency. ${ }^{51}$ A Discrimination Law Review team has been established to consider the reform and codification of anti-discrimination legislation. ${ }^{52}$ The momentum towards greater legislative coherence is well on course: it remains to be seen whether the lingering conceptual uncertainty about the ultimate status and importance of antidiscrimination law will derail or delay the train..$^{53}$

However, real issues remain to be resolved before a unified and comprehensive anti-discrimination legislative framework can be put into place. Firstly, drafting a comprehensive anti-discrimination code will not be easy. Some questions are technical: should age discrimination legislation be applied to the provision of insurance services, and if so, what exceptions should be permitted? What is the most appropriate definition of disability?

49 The Disability Rights Commission Act 1999; Special Educational Needs and Disability Act 2001.

50 The Disability Discrimination Act 2005 has extended the definition of disabled status to include HIV status, certain forms of cancer and previously excluded forms of mental illness. It also now extends to the performance by public authorities of their public functions (see later). For the impact of the Directive and the Disability Regulations 2003, see K. Wells, "The Impact of the Framework Equality Directive on UK Disability Discrimination Law" [2003] 32(4) ILJ 253273, 256-257.

51 Lord Lester introduced a private members' bill into the House of Lords in 2003 that provided for the introduction of unified and coherent anti-discrimination legislation. For the text of this bill, see http://www.odysseustrust.org/equality.html

52 See www.dti.govuk/weu

53 Moves in Northern Ireland to introduce a single equality bill will inevitably add momentum to developments in the UK. An Equalities Review has been established to examine the causes for inequality in Britain under the chairmanship of Trevor Phillips, which will report to the Prime Minister in summer 2006. It will be curious to see if this Review will uncover anything that is not already wellestablished in the literature on the causes of group disadvantage in Britain. 
Should employers be liable for harassment suffered by their employees as a result of the actions of third parties? ? $^{54}$

Another set of issues arise as to how far should reform of the basic framework of British anti-discrimination legislation go. For example, there is a strong case for an overhaul of the existing system of remedies in discrimination cases, and in particular for greater scope to be given to courts and tribunals to award exemplary damages and to grant wider forms of injunctive relief. ${ }^{55}$ Serious consideration could also be given to removing the requirement to demonstrate that a complainant was treated less favourably than a comparator, which is a common requirement across most of British anti-discrimination law, and focusing instead on establishing whether the complainant has been subject to a disadvantage linked to one of the equality grounds. The comparator requirement is a lingering legacy of the distorting effect of "equality as sameness" rhetoric. It generates complex and messy difficulties of proof, and often operates to blunt the impact of antidiscrimination law without having any real basis in firm principle. ${ }^{56}$

However, deciding whether to enhance available remedies and to reform the comparator requirement requires a decision on the extent to which the legislation should be pushed to give more effect to its transformative aspirations. It also requires decisions as to what countervailing weight should to be given to apparently competing considerations, such as neoliberal concerns for the autonomy of private market actors. A lack of consensus exists as to how far the "social engineering" aspirations of equality law should or can be pushed: this means that shaking off the inertia and caution that has prevailed in this area for years may prove difficult.

Other reform issues raise other fundamental questions of principle: extending the legislation in this way is not simply a matter of converging upon common standards, and removing insupportable inconsistencies. Real tensions exist between the claims of different groups as to what will constitute "equality of treatment" for them. For example, the claims of religious groups to be able

54 The decision in Burton and Rhule v DeVere Hotels [1997] ICR 1 had established that employers could be liable for third-party harassment, but in Pearce $\mathrm{v}$ Mayfield Secondary School Governing Body [2003] UKHL 44, the House of Lords overruled Burton on the basis that the legislation required that the employer had to subject the employee to less favourable treatment than another employee for liability to arise.

55 See S. Fredman, Discrimination Law, 170-73. For an example of the use of a wider range of injunctive relief by the Canadian courts, see J. H. Beck, J. G. Reitz, and N. Weiner, "Addressing Systematic Racial Discrimination in Employment: The Health Canada Case and Implications of Legislative Change" (2002) 28 (3) Canadian Public Policy 373-394.

56 See Fredman, ibid., p.57. This would reduce some of the complexities generated by the requirement to point to a comparator, and replace this test with the more workable and arguably more just approach that would ask whether the complainant had suffered disadvantage on a prohibited ground. This is already the approach adopted under the DDA: see Clark v Novacold [1999] 2 All ER 977 (CA), and S. Fredman, "Disability Equality: A Challenge the Existing AntiDiscrimination Paradigm?", in A. Lawson and C. Gooding, Disability Rights in Europe (2005) 199-218. Evidence of treatment of comparators would still be used for evidential purposes. 
to maintain the "religious ethos" of educational and other establishments may come into conflict with the expectations of lesbian, gay and transsexual groups, or secular groups, or women. This has already generated litigation in the employment context, ${ }^{57}$ and is likely to do so again when protection against religious discrimination is extended by the Equality Bill to the provision of goods and services, including education. ${ }^{58}$

These are issues to which the current "under-theorised" understanding about how British equality norms should be framed cannot readily supply answers. British anti-discrimination legislation is slowly gaining more coherence, clarity and consistency. However, the reform of the legislation is also throwing up wider issues. The transformative aspirations of equality norms are coming up against conflicting considerations, issues about what inclusion means for different groups, and questions about what form of society should be the end goal of any transformative process. ${ }^{59}$ There may be a danger that in the absence of conceptual clarity and real debate, achieving a uniformity of approach across the different grounds may substitute for the establishment of a truly coherent framework based on justifiable and well-reasoned moral, social and legal considerations.

\section{The Commission for Equality and Human Rights}

Similar conceptual issues arise with respect to the impending establishment of a common, cross-ground enforcement framework in the form of the Commission for Equality and Human Rights. The Commission's remit will extend across all the equality grounds and beyond to wider rights issues, including the promotion of good relations between different communities and "groups" in British society. ${ }^{60}$ The existing British equality commissions

57 See art.4(2) of the Framework Equality Directive, Regulation 7(3) of the Employment Equality (Religion or Belief) Regulations 2003, Regulation 7(3) of the Employment Equality (Sexual Orientation) Regulations 2003, and the discussion of the appropriate scope to be given to this "religious ethos" exception as incorporated into UK law by the implementing regulations in $R$ (Amicus) $\mathrm{v}$ Secretary of State for Trade and Industry [2004] EWHC 860 (Admin).

58 The prohibition of harassment on the grounds of religious belief in the provision of education has already generated a set of complex exemptions in the Equality Act 2006, and generates worrying concerns about free speech protection. See Hansard (H.L.), October 19 2005, cols. 819-832. See also the current controversy over the introduction of incitement to religious hatred legislation.

59 An interesting question is whether anti-discrimination legislation should be extended to other grounds not currently covered in UK or EC law, such as socioeconomic status or carer responsibilities. For a comparative analysis of the varying scope of anti-discrimination law across the globe, see S. Kilcommins et al, Extending the Scope of Employment Equality Legislation: Comparative Perspectives on the Prohibited Grounds of Discrimination (2004). There is a danger that the extension of anti-discrimination could weaken the integrity of the existing legislation, by overreaching and establishing unenforceable norms. However, serious consideration could at a minimum be given to prohibiting discrimination on the grounds of carer responsibilities, and perhaps on other grounds as well.

60 The broad concept of human rights is supposed to serve as an overarching and unifying conceptual framework that will give coherence to the Commission's work. Department of Trade and Industry, Fairness for All: A New Commission for Equality and Human Rights (2004) Cm 6185, paras.1.10-1.11. 
will be gradually merged within the new Commission. This is controversial. Serious reservations have been expressed that the specific needs of the different equality grounds would be submerged and overlooked in the new structure. However, the government considered that a single Commission would be more successful in promoting equality of opportunity than would a set of several autonomous and separate commissions. ${ }^{61}$

There is a legitimate degree of concern that a single Commission may be more vulnerable to governmental pressure, bureaucratic inertia and/or to an overemphasis upon a "one size fits all" approach. ${ }^{62}$ How well the Commission will perform its role will partially depend upon its leadership, its working practices, and how it chooses to use its statutory powers. However, a single Commission may be in a better position to push for widespread social change, and to emphasise the interconnectedness of antidiscrimination entitlements and other human rights, than would a multiplicity of different bodies. ${ }^{63}$ What a single Commission may not be able to do is to give a political and representative voice to the different communities in Britain that currently look to the existing equality commissions to articulate their views. Trevor Phillips, the chair of the Commission for Racial Equality, has called for the establishment of a new Commission for Citizenship and Integration to work alongside the new Commission, partially perhaps due to concerns that the new Commission would be unable to address many of the policy issues that particularly concern black and other ethnic minority communities ${ }^{64}$ This dispute reflects an interesting difference of opinion as to the appropriate role of equality and human rights commissions: should its primary focus be on combating discrimination, denial of rights and social

61 Fairness For All suggested that a single commission should be more capable of dealing effectively with issues of multiple and overlapping forms of discrimination, making more effective use of resources and expertise, and encouraging best practice in its cross-ground equality work. Ibid., paras.1.14-1.17. In any case, there was a need to ensure that the new sexual orientation, age and religious belief regulations were enforced, and establishing three new commissions was simply not a viable option. Controversy has persisted as to the appropriate internal structure of the Commission, and whether specific subcommittees are needed to ensure an adequate focus upon the needs of the different equality grounds.

62 See the arguments made by the 1990 Trust, Our Rights, Our Future (2004)

63 C. O'Cinneide, A Single Equality Body: Lessons from Aboard (2002), at pp.7-9. During the consultation process that predated its establishment, many activist groups argued that without comprehensive and unified equality legislation, a single Commission would be unable to operate in a coherent and effective manner. This was a tactically useful political argument, to push for more coherent legislation. However, it was not necessarily true: the experience of other jurisdictions has shown that single commissions can operate effectively even in the absence of unified equality legislation. See C. O'Cinneide, A Single Equality Body: Lessons from Aboard, p.9-10. Uniformity of legislation is not a precondition for an effective single Commission, and uniformity of approach could be a dangerous and unrealisable ambition.

64 See CRE Chair Calls for New Commission and New Rules for Integration, CRE press release, 30 November 2005. Some of this concern stemmed from the recommendation in a consultant's report to locate the bulk of the Commission's staff in Manchester, and not in London with its considerable proportion of Britain's ethnic minority communities. 
exclusion, or should it also be expected to play a major role in representing the needs of particular communities? This again reflects the recurring uncertainty underlying equality law and policy in Britain: can the enforcement and promotion of equal rights be separated from the articulation of group identities?

Other issues arise in respect of the powers of the new Commission. The Disability Rights Commission, Equal Opportunities Commission and the Commission for Racial Equality have attempted to combine promotional and enforcement work through the strategic use of their investigative and case support powers. ${ }^{65}$ The legislation establishing the new commission is designed to enable the Commission to develop a similar strategic approach, and to strengthen and clarify the Commission's powers and functions. ${ }^{66}$ The legislation also places the Commission under a "general duty" to use its powers and functions to work towards the development of a society where equality and rights principles have become rooted, which is defined as follows:

“(a) people's ability to achieve their potential is not limited by prejudice or discrimination,

(b) there is respect for and protection of each individual's human rights (including respect for the dignity and worth of each individual),

(c) each person has an equal opportunity to participate in society, and

(d) there is mutual respect between communities based on understanding and valuing of diversity and on shared respect for equality and human rights." 67

This constitutes a fascinating attempt to give a legislative definition to the idea of a rights-based society. More pragmatically, its width also gives the Commission a wide field of action. Along with greater statutory clarity as to the scope of its enhanced powers, this should help reduce the risk of narrow judicial interpretation of its powers, duties and functions that has occasionally plagued the existing commissions. ${ }^{68}$ However, the retention of limits on the investigatory powers of the new Commission will not permit it to carry out the intensive inspectorate role that the equality commissions

65 See J. Clarke and S. Speeden, Then and Now: Change for the Better? (2001); N. O'Brien, "The GB Disability Rights Commission and Strategic Law Enforcement: Transcending the Common Law Mind", in A. Lawson and C. Gooding, Disability Rights in Europe (2005), 249-263.

66 The Equality Act 2006 gives new powers to the CEHR, including the power to enter into binding agreements with other bodies who will undertake to avoid discriminatory acts (this power is currently held by the DRC, but not by the other two existing commissions). The legislation also clarifies the scope of its investigatory powers, and it has been given a new power to enforce the general positive equality duties: see below.

67 S.3 of the Equality Act 2006: more specific duties are imposed in respect of the Commission's equality functions in $\mathrm{s} .7$ and its human rights functions in s.8.

68 See C. McCrudden, "The Commission for Racial Equality: Formal Investigations in the Shadow of Judicial Review" in P. Craig and C. McCrudden, Regulation and Public Law (1987) 227-266. 
were originally intended to play. ${ }^{69}$ The fear of "social engineering" and potential backlash means that it has been denied a radical transformative role.

\section{Part Three: Equality Norms as Constitutional Controls upon Public Authorities}

\section{Anti-Discrimination Controls on Public Authorities}

Similar problems arise in respect of the gradual extension of British equality law to the vertical relationships between individuals, groups and the state. As discussed above, any coherent and effective structure of equality norms needs to address how the state maintains or permits the making of distinctions between different groups. However, British anti-discrimination law has historically not extended to instances where the exercise of state power has been at stake. This deficient coverage has constituted perhaps the single most gaping hole in British equality law.

One aspect of this gap was highlighted by the controversy that followed the death of Stephen Lawrence, and the subsequent findings of the Macpherson Report, which threw a spotlight upon the exemption of public authorities from anti-discrimination legislation when performing public functions. This exception was a typical example of an incoherent lacuna in British antidiscrimination legislation. It originated not from any particularly reasoned foundation in principle, but from a narrow interpretation of the Sex Discrimination Act by the House of Lords in Amin v Entry Clearance Officer Bombay. ${ }^{70}$ The result of this was that the decisions of public authorities in many core areas of public sector activity, such as immigration control and policing policies, were exempt from any possibility of challenge on antidiscrimination grounds. ${ }^{71}$

69 See A. Lester, "Discrimination: What Lawyers Can Learn From History", 226-7. See also M. Munroe, "The Prestige Case: Putting the Lid on the Commission for Racial Equality" (1985) Anglo-American Law Review 187, G. Appleby and E. Ellis, "Formal Investigations: The Commission for Racial Equality and the Equal Opportunities Commission as Law Enforcement Agencies" [1984] Public Law 236.

70 [1983] 2 AC 518 (HL). Despite a strong dissent from Lord Scarman, the majority in Amin recognised a distinction between the provision by public authorities of goods and services analogous to those provided by private bodies, and the performance of public functions. As the legislation did not specifically apply to this latter type of activity, the Law Lords held that public authorities were not bound by anti-discrimination legislation when performing public functions. See C. O'Cinneide, "The Race Relations (Amendment) Act 2000" [2001] Public Law 221.

71 It also generated complex and largely incoherent distinctions between matters which were exempt from the legislation, and matters that fell within its scope. Tax advice from a tax officer was treated as a type of service analogous to services delivered by private bodies, and so could be subject to the legislation, while the assessment and collection of the actual taxes were public functions and so could not: see Savjani v Revenue Commissioners [1981] QB 458. Obtaining assistance from a police officer was a service covered by the legislation, but not decisions to arrest or prosecute: see Farah v Commissioner of Police of the Metropolis [1998] 
In the wake of the Macpherson Report, the Race Relations (Amendment) Act 2000 extended the legislative prohibition on direct and indirect race discrimination to public authorities performing public functions, with exemptions for judicial and prosecutorial decisions, the armed forces, the intelligence services and for certain immigration and asylum functions. ${ }^{72}$ Subsequently, the Disability Discrimination Act 2005 extended the disability discrimination legislation to cover the performance of public functions. The Equality Act 2006 makes similar provision for the sex discrimination legislation, and the prohibition on discrimination on the grounds of religious belief and sexual orientation will also be extended to the performance of public functions by this legislation. Similar exemptions for all of these grounds are established as those introduced in the Race Relations (Amendment) Act. ${ }^{73}$ These reforms represent a significant recognition that vertical citizen-state relationships need to be subject to similar controls as horizontal relationships.

This extension of the legislation greatly expands the scope of antidiscrimination controls upon public authorities, especially as they are now subject to the full rigour of the prohibition on direct discrimination. The impact of this can be seen in $R$ (European Roma Rights Centre) v Chief Immigration Officer, Prague Airport, where the Law Lords held that the singling-out of Roma travellers to the UK for special pre-entry clearance scrutiny constituted direct race discrimination. ${ }^{74}$ The Law Lords rejected the Court of Appeal approach in the same case, which deviated from the standard approach to determining direct discrimination claims, and applied the legislation in its full rigour to public authorities. ${ }^{75}$

QB 65. See also B. Hale, "The Quest for Equal Treatment" [2005] Public Law 571-585, 575; A. McColgan, Discrimination Law (2nd ed.) (2005) 271-280.

72 See C. O'Cinneide, “"The Race Relations (Amendment) Act 2000", [2001] Public Law 220. Note that the UK government was initially very reluctant to extend protection against indirect race discrimination to the performance of public functions, which subsequently became the central issue in $R$ (Elias) v Secretary of State for Defence [2005] EWHC 1435 (Admin): see below. The exceptions for immigration and asylum functions, which permit discrimination on the basis of nationality, national origin and ethnic origin if authorised by the Secretary of State, remain controversial: see A. Dunnett, The Immigration Exception in the Race Relations (Amendment) Act 2000 (Immigration Law Practitioners Association, 2001). See also C. O'Cinneide, "The Race Relations (Amendment) Act”, [2001] Public Law 220, 227.

73 An exception to the extension of the sex discrimination legislation permits public authorities to provide services to one sex only, while the religious belief extension exempts some narrowly defined immigration decisions from the scope of the prohibition: the exemptions for judicial and prosecutorial decisions, the armed forces, and the intelligence services are common across the grounds.

74 [2004] UKHL 55.

75 [2003] EWCA Civ. 666. In the Court of Appeal, Simon Brown LJ (as he was then) and Mantell LJ had considered that the unequal treatment of Roma travellers was not based upon their ethnic origin, but rather upon the greater statistical tendency for Roma travellers to the UK to make asylum claims: as a result, they held that no race discrimination had occurred. This reasoning disregarded the fact that the difference of treatment was triggered by membership of that particular group, and 
Similarly, in $R$ (Elias) v Secretary of State for Defence, ${ }^{76}$ Elias J. held that the exclusion of British civilians interned by the Japanese during World War Two from an ex-gratia compensation scheme, unless they had been born in the UK or had a parent or grandparent born there, constituted unjustifiable indirect discrimination on the grounds of national origin, contrary to the Race Relations Act. In applying the standard justification test, Elias J. accepted that it was a legitimate aim for the government to wish to direct benefits towards British citizens with a strong link with the country. However, he considered that the method chosen to give effect to this aim was disproportionate. Alternative criteria could have been used, such as requiring a period of residence or domicile in the UK before eligibility could arise, which would have focused less upon the "racial" or "bloodline" element of citizenship, and more on whether a tangible link existed with the UK. ${ }^{77}$

It remains to be seen what impact the extension of anti-discrimination legislation across the other grounds to include the performance of public functions will have, and in particular what forms of justification for indirect discrimination will be accepted by the courts. The decisions in Roma Rights and Elias illustrate its potential impact. However, anti-discrimination legislation does not apply to acts done under the authority of an Act of Parliament, nor can it override other statutory provisions. By itself, it is insufficient to protect against unfair discrimination in vertical relationships. There is a need for "constitutional" equality norms that will steer the interpretation of legislation in a way that maximises protection against discriminatory impact, and provide for the possibility of judicial review challenges to state action that results in unequal treatment. ${ }^{78}$

\section{Equality as a Constitutional Norm}

For most of the twentieth century, equality and non-discrimination principles have not been recognised as occupying a meaningful place in the set of common law values, beyond ritual obeisance in judicial pronouncements and academic rhetoric to Dicey's concept of the formal equality of all beneath the

therefore fell squarely within the definition of direct discrimination adopted by the Law Lords in James v Eastleigh Borough Council [1990] 2 AC 751. Rabinder Singh QC has described the approach of the majority in the Court of Appeal as attempting to introduce a defence of justification into direct discrimination when the legislation is applied to public authorities: see R. Singh, "Equality: The Neglected Virtue" [2004] EHRLR 141-157, 152-154. In $R$ (Gillen) v Commissioner for the Metropolis [2006] KHL 12, Lords Hope and Brown accepted that the singling-out of individuals for searches under anti-terrorism legislation on the basis of ethnicity alone would be unlawful under the Race Relations Act. This would appear to confirm the "strict" approach applied in Prague Airport.

76 [2005] EWHC 1435 (Admin)

77 This nuanced judgment is notable for the recognition by Elias J. of how concepts of ethnic origin, national origin and citizenship are intertwined.

78 The term "constitutional" norm is used here to describe underlying legal principles that shape the application of public law controls and the interpretation of legislation. 
rule of law. ${ }^{79}$ This meant that anti-discrimination legislation was often regarded as carving out exceptions to established common law principles such as freedom of contract and association, and should therefore be narrowly interpreted. ${ }^{80}$ It also meant that when public authorities did take action to promote equality of opportunity, this was sometimes deemed to lack sufficient weight to out-balance other competing considerations. ${ }^{81}$ In contrast, if public authorities introduced discriminatory measures, the lack of any form of equality principle in the common law meant that, in McCrudden's phrase, "no positive principle of opposition" existed to ground a challenge to these policies. ${ }^{82}$

However, Jowell in a seminal article in 1994 suggested that a series of judicial review decisions had recognised that certain forms of distinction could be considered unjust, unfair and contrary to common law values, and these decisions could be interpreted as disclosing the existence of a common law equality principle. ${ }^{83}$ This principle had a "formal" dimension in requiring that individuals and groups in similar positions should be treated alike. However, it could also be interpreted as having a "substantive" dimension, as certain forms of differentiation as intrinsically suspect, and prevented the making of "distinctions which were not properly justified" or which "ultimately [force] the citizen to relinquish her or his sense of equal worth" ${ }^{84}$ Jowell therefore argued for the recognition in the common law of a presumption that certain forms of unjust distinctions should not be permitted to be applied or maintained by public authorities.

Subsequent criticism suggested that that this "equality principle" was better understood as involving no more than an application of the well-established requirement that public authorities had to act rationally: again, the conceptual

79 See A. Lester and G. Bindman, Race and the Law (1972). See also the extensive critique in A. McColgan, "Discrimination Law and the Human Rights Act 1998" in T. Campbell, K.D. Ewing and A. Tomkins (eds), Sceptical Approaches to Human Rights (2001) 215-241, 218-224.

80 See Charter v Race Relations Board [1973] AC 868; Dockers' Labour Club v Race Relations Board [1976] AC 285; $R$ v CRE, ex p. Hillingdon Borough Council [1982] A.C. 779; In re Prestige [1984] I.C.R. 473; Amin remains the classic example: Amin v Entry Clearance Officer Bombay [1983] 2 AC 518 (HL). See also D. Oliver, Common Values and the Public-Private Divide (1999), at 208.

81 See Roberts v Hopwood [1925] AC 578; R. v Lewisham LBC Ex p. Shell UK [1988] 1 All E.R. 938

82 See McCrudden, "Equality and Non-Discrimination", para.11.18, p.587. See also Ahmad v Inner London Education Authority [1978] 1 All E.R. 574.

83 J. Jowell, "Is Equality a Constitutional Principle" (1994) 7 Current Legal Problems 1. See in particular Nagle v Feilden [1966] 2 QB 633, where a common principle of access to work and a profession was applied so as to prevent the Jockey Club denying training licences to women. See also Oppenheimer v Cattermole (Inspector of Taxes) [1976] AC 249; however, contrast Blathwayt v Cawley (Baron) [1976] A.C. 397, Re Lysaght (Deceased) [1966] Ch. 191, and the scepticism expressed by Hoffmann L.J. (as he was then) in $R \vee$ Jockey Club, ex $p$. Aga Khan [1993] 1 WLR 916 about the decision in Nagle

84 Jowell, ibid, p.7, 18. See also T. Allan, "The Rule of Law as the Rule of Reason: Consent and Constitutionalism" (1999) 115 LQR 221, 244. Jowell also suggested that the substantive element of this principle could justify a departure from sameness of treatment, where a difference of treatment was "justified in the particular case (to achieve substantive equality)”. See Jowell, p.14. 
quicksand that lurks beneath equality legal norms loomed. ${ }^{85}$ Nevertheless, Jowell's analysis and terminology has been adopted by the courts. The Privy Council in Matadeen v Pointu recognised that this principle of equality in Lord Hoffmann's words was “one of the building blocks of democracy and necessarily permeates any democratic constitution. . . treating like cases alike and unlike cases differently is a general axiom of rational behaviour." 86

This has opened the door to a new approach to the application of common law norms and legislative provisions. ${ }^{87}$ Legislation which is not directly concerned with the prohibition of discrimination has been interpreted so as to prevent disadvantage arising as a consequence of a suspect classification, most significantly in Fitzpatrick v Sterling Housing Association. ${ }^{88}$ In $R \mathrm{v}$ Secretary of State for Defence ex $p$. Smith, the Court of Appeal held that administrative practices which make use of discriminatory classifications have to be shown to satisfy a heightened standard of scrutiny. ${ }^{89}$

However, the extent of this shift remains uncertain. The scope and ambit of this equality principle remains less than clear: for example, the extent to which private law will be affected remains an open question. ${ }^{90}$ The requirement to show that the use of suspect forms of classification satisfies the "heightened scrutiny" test may not in practice constitute a very stringent

85 See J. Stanton-Ife, "Should Equality Be a Constitutional Principle?" (2000) 11 (2) King's College LJ 133-152. McColgan has argued that in actuality, the cases relied upon by Jowell disclose no meaningful principle of equality, and "any judicial commitment to non-discrimination appears to have been honoured significantly in the breach": see McColgan, "Discrimination Law and the Human Rights Act 1998 ", 224.

86 [1999] 1 AC 98, 109C, citing Rault J. in Police v Rose [1976] MR 79, 81 in support. See also de Smith, Woolf and Jowell, Judicial Review of Administrative Action (London: Sweet \& Maxwell, 1995) (5 ${ }^{\text {th }}$ ed.), paras.13-036 to 13-045, pp.576-582.

87 In $R$ v $R$ [1992] 1 AC 599, the House of Lords overturned the common law rule that a husband could not be prosecuted for raping his wife. For another example of this new approach, the tort of misfeance in public office has been recognised as capable of encompassing discriminatory acts: see Thomas v Secretary of State for the Home Department, QBD, 31 July 2000, per Buckley LJ. See also McCrudden, "Equality and Non-Discrimination", p.643.

88 [2001] 1 AC 27. See also Lambert v Lambert [2002] EWCA Civ. 1685.

89 [1996] QB 517, 554. See also $R$ v Secretary of State for the Home Department, ex p. Daly [2001] UKHL 26, para.27, per Lord Bingham.

90 Lord Hoffmann in Hall v Simons [2000] 3 WLR 543 described the equal treatment of those in similar categories as a "fundamental principle" of the common law (560 E-F). See also Oppenheimer v Cattermole [1976] AC 249, especially 277278; D. Oliver, Common Values and the Public-Private Divide (London: Butterworths, 1999), 64. However, as yet, it is not clear to what extent equality and anti-discrimination values will be applied in common law decision-making when private parties are concerned, and in particular to what extent equality norms can be considered as part of "public policy". For an interesting discussion of this issue in the North American context, see A. Reichman, "Professional Status and the Freedom to Contract: Toward a Common Law Duty of Non-Discrimination" (2001) 14(1) Canadian Journal of Law and Jurisprudence 79-132. See also L. Leger, "The Culture of the Common Law in the 21st Century: Tort Law's Response to the Needs of a Pluralist Society" in K. Cooper Stephenson and E. Gibson, Tort Theory (1993), 162. 
degree of scrutiny. ${ }^{91}$ Even the very existence of this general equality principle seems to be uncertain. In Association of British Civilian Internees (Far Eastern Region) v Secretary of State for Defence, the Court of Appeal cast doubt on whether the Privy Council had in fact recognised the existence of a common law equality principle in Matadeen, suggesting that Lord Hoffmann's discussion in the earlier case was best interpreted as analysing how to apply the standard Wednesbury irrationality approach in the context of alleged unjustified discrimination. ${ }^{92}$

However, in Gurung v Ministry of Defence, McCombe J. regarded the exclusion of Gurkha soldiers from the scheme of compensation payments awarded to former P.O.Ws of the Japanese as based on de facto racial distinctions. ${ }^{93}$ Their exclusion was therefore held to be irrational and contrary to the common law principle of equality, which was recognised without hesitation as an integral common law norm. McCombe J. rejected the Government's attempt to rely upon a formal distinction between units of the British and Indian Armies as a purely formalistic de jure attempt at "fossilising rationality in its 1951 form", which "disguised" the true racial nature of the distinction. ${ }^{94}$

Gurung represents the most rigorous and far-reaching application of the Matadeen equality principle yet, and demonstrates that it can have real "bite". However, uncertainty remains as to the scope and content of this principle. Lord Hoffmann in Matadeen identified the problem:

"the very banality of the principle must suggest a doubt as to whether merely to state it can provide an answer to the kind of problem which arises in this case. Of course persons should be uniformly treated, unless there is some valid reason to treat them differently. But what counts as a valid reason for treating them differently? And, perhaps more important, who is to decide whether the reason is valid or not?" 95

Lord Hoffmann therefore suggested that this underlying conceptual uncertainty meant that in many cases it was suitable for the decision as to when and how this principle should be applied to be left to the legislature. ${ }^{96}$

91 See McCrudden, "Equality and Non-Discrimination”, p.611-615

92 [2003] EWCA Civ. 473, especially paras.85-86. Following this interpretation, the Court of Appeal applied the normal Wednesbury irrationality test to deny the claimants relief.

93 [2002] EWHC 2463 Admin.

94 Notably, McCombe J. used the example of the decision in Short v Poole Corporation [1926] Ch 66, where the Court of Appeal upheld the termination of a woman teacher's employment contract by a local authority after being satisfied that her husband could maintain her, as an example of the "danger of decisionmakers today adopting a 'rationality' based upon the criteria of yesterday". As McCrudden notes, this shows that what he describes as the "grounds of unacceptability" may change over time: see McCrudden, "Equality and NonDiscrimination", para.11.149, p.648.

95 [1999] 1 AC 98, 109.

96 See also the comments of Lord Hope in Relaxion Group v Rhys-Harper plc [2003] UKHL 33, para.78: "although discrimination on whatever grounds is widely regarded as morally unacceptable, the common law was unable to provide a sound basis for removing it. . Experience has taught us that this is a matter which can 
The lack of clarity and consensus on the proper application of equality principles does mean that a resolution of many of the issues involved has to come from the legislature, as the appropriate forum for resolving such questions. However, this need not result in total judicial paralysis in the face of equality claims. As argued above, even in the absence of complete conceptual consensus, a sufficient degree of agreement now exists that a coherent framework of equality law should form part of the legal and social fabric of Britain. Decisions such as Gurung, where administrative action relied upon discriminatory classifications without any real tangible justification, can be said to violate contemporary standards of due respect for equality norms. It may be difficult to define with precision the source of these standards, or exactly what behaviour they do require. However, Jowell's suggestion that it is consistent with the logic of the common law to apply a presumption against the use of discriminatory criteria is clear, coherent and in line with contemporary understanding of equality norms. It therefore can serve as an operable and useful legal concept, notwithstanding the existence of some underlying conceptual issues. ${ }^{97}$

Therefore, the courts should be prepared to apply this common law principle, within the limits of their constitutional role. ${ }^{98}$ The use of common law values by the judiciary plays an important role in steering the application of legal norms, whether these norms are legislative in nature or generated through the common law. Without the recognition and application of common law equality principles, then what Lester and Bindman described as the "ethical aimlessness" of the common law may ensure that protection against discrimination will be severely limited. ${ }^{99}$ It may even result in the triumph by default of the traditional common law emphasis upon individual and corporate autonomy, in those circumstances where legislation does not provide a clear answer.

It is also essential that the importance of this equality principle be recognised in interpreting anti-discrimination legislation, and where appropriate that a purposive interpretation be given. Anti-discrimination legislation is supposed to be the appropriate tool to prevent the use of the illegitimate distinctions. However, narrow judicial interpretation of anti-discrimination legislation, combined with its often crabbed and impenetrable drafting, ${ }^{100}$ has often tended to reduce its impact. However, with the shift towards judicial

only be dealt with by legislation, and that it requires careful regulation by Parliament. . . The fact is that the principle of equal treatment is easy to state but difficult to apply in practice".

97 It can once again be seen as a classic instance of Sunstein's concept of an "undertheorised" legal principle that nevertheless attracts sufficient agreement and has sufficient legal clarity to be fully operable within a legal system: see the discussion in Part One. A similar development in the case-law of the ECJ has seen equality recognised as a general principle of EC law: see Case 319/03 Briheche v Ministre de l'Intérieur [2005] 1 C.M.L.R. 4, and the opinion of Advocate-General Stix-Hackl in Case C-186/01, Dory v Germany [2003] ECR I-2508.

98 The question of what is the appropriate constitutional role of judges in developing common law values is of course a fiercely contested issue, which lies outside the scope of this paper.

99 A. Lester and G. Bindman, Race and the Law (1972). See also A. Lester, "English Judges as Law-makers" [1993] PL 269.

100 See A. Lester, "Discrimination: What Can Lawyers Learn From History", 227. 
recognition of a common law principle of equality, the courts have begun to embrace a more purposive approach to the legislation. McCrudden traces the beginnings of this shift back to the early 1980s, in cases such as Home Office v $C R E^{101}$ and Mandla v Lee. ${ }^{102}$ However, the English and Scottish courts have continued to oscillate between narrow and more purposive approaches to the legislation up to the present day.

Nevertheless, recent decisions by the Law Lords have adopted a firm preference for a purposive approach to anti-discrimination legislation, which recognises the underlying logic of the legislation and how it should favour interpretations that enhance protection against discrimination. In Relaxion Group v Rhys-Harper plc, the Law Lords applied this purposive approach in finding that the SDA, RRA and DDA could apply to the post-employment relationship. ${ }^{103}$ In Archibald v Fife County Council, the Lords took a similar approach in finding that the obligation to make reasonable accommodation in the DDA could require employers to waive standard procedures for selecting individuals to fill posts in order to accommodate a disabled person. ${ }^{104}$ The traditional emphasis placed in common law adjudication upon the narrow construction of anti-discrimination provisions, the maintenance of employer "merit" requirements, and the rejection of forms of special treatment for disadvantaged persons are all absent from Archibald. A similar purposive stance can be seen in the expansive approach adopted in interpreting the DDA definition of disability by Morison LJ in Goodwin v The Patent Office. ${ }^{105}$

This gradual shift offers the potential for a more principled and coherent approach to how anti-discrimination legislation is judicially interpreted. It also reduces the potential for the generation of more Amin-style formalist distinctions, which tend to be unsustainable and ultimately require more legislative tinkering and judicial creativity. However, it remains to be seen whether this new purposive approach will prove to be applied consistently by the courts. This shift may also not have fully percolated through to the employment tribunals, where crabbed and formalist interpretations of the legislation persist. ${ }^{106}$

In general, given the inherent conceptual vagueness underpinning British equality norms, it is difficult to see how a common law equality principle can be pushed much further than applying a reasonably strong presumption against unequal treatment on the grounds of suspect criteria in judicial review. Similarly, a purposive interpretative approach can only extend to favouring a reading of the legislation that advances protection against unfair discrimination where real statutory ambiguity exists. How both approaches

101 [1982] QB 385

102 [1083] AC 548, HL. See McCrudden, "Equality and Non-Discrimination", pp.604-5.

103 [2003] UKHL 33

104 [2004] UKHL 32

105 [1999] ICR 302; for another example in the disability context, see Collins v Royal National Theatre Board [2004] EWCA Civ. 144.

106 See the cri de coeur by Juliette Nash in Discrimination Law Association, Briefings 377-390, Vol. 26, October 2005, 390: "after thirty years of European influence upon English courts, it is clear that expecting the EAT to give anything resembling a purposive interpretation to legislation is most unwise". 
are applied will also be affected by the underlying conceptual uncertainty of equality norms. This will inevitably generate a degree of fluctuating caselaw and alternative approaches. Pending greater agreement on salient conceptual issues, it is useful that these approaches have evolved, but their impact will inevitably vary.

\section{The Human Rights Act}

In any case, any development of the common law principle will not permit challenges to legislation that has a discriminatory impact. ${ }^{107}$ Similarly, the cultivation of purposive approaches to interpreting anti-discrimination legislation can only go so far: no scope for manoeuvre exists when this approach comes up against the limits of the statutory language. ${ }^{108}$ Ensuring adequate protection against denial of equal status in vertical relationships requires some mechanism for scrutinising legislation for compatibility with equality norms. As Lady Hale has suggested, "insisting the laws themselves do not discriminate" is a necessary part of any legal solution to the problems caused by prejudice and group stereotyping. ${ }^{109}$ The Human Rights Act (HRA), by making such scrutiny possible, is therefore another step along the path of establishing a coherent and effective equality and anti-discrimination framework. In addition, the Convention rights provide a firmer basis for challenging discriminatory acts by public authorities: the proportionality standard of review to be applied under the European Convention on Human Rights (ECHR) is more rigorous and difficult to satisfy than the common law "reasonableness" standard. ${ }^{110}$

However, while the HRA may constitute another step towards coherence, at present it can only offer a stunted form of protection against discrimination, and its transformative impact is limited. ${ }^{111}$ Even before the enactment of the HRA, the European Court of Human Rights had found a series of UK

107 There have been recent judicial suggestions that legislation may not be given effect by the courts if it violates fundamental common law norms: see Lord Woolf, 'The Rule of Law and a Change in the Constitution' (2004) 63 Cambridge LJ 317-330, and the obiter opinions of Lord Steyn and Lord Hope in Jackson v Attorney General [2005] UKHL 56. This shift in the traditional constitutional position, described by Lord Steyn as a "different hypothesis of constitutionalism", rests on uncertain grounds: if it takes root, however, the equality principle may very well be deemed to constitute one of these fundamental values, and a breach of core anti-discrimination norms could trigger a refusal to apply the relevant legislation. It is significant that Lord Steyn cited the South African decision of Harris v Minister of the Interior 1952 (2) 428 (AD) to illustrate his argument: this case saw the South African Appeal Division block the introduction of apartheid measures.

108 For an example, see McDonald v Advocate General for Scotland [2003] UKHL 34

109 See B. Hale "The Quest for Equal Treatment" [2005] PL 571-585.

110 See the judgment of the European Court of Human Rights in Smith and Grady v $U K$ (2000) 29 EHRR 493. In $R$ v Secretary of State for the Home Department, ex p. Montana [2000] EWHC Admin 421 (23rd November, 2000), the High Court considered that the common law principle of equality did not add much to the scope of art.14, and would only be considered where art.14 not applicable.

111 S. Livingstone, "Article 14 and the Prevention of Discrimination in the European Convention on Human Rights" (1997) 1 EHRLR 25. 
legislative and administrative acts that impacted upon particular disadvantaged groups incompatible with the Convention: the Article 8 guarantee of personal privacy had proved a particularly effective avenue of challenge. ${ }^{112}$ However, there was no great anticipation that the HRA would have a major impact in the field of equality and anti-discrimination. ${ }^{113}$ This was due to the well-known fact that unlike other national or international human rights instruments, the ECHR contains at present no free-standing right to equality: Article 14 of the Convention only guarantees equality of treatment in the enjoyment of other Convention rights. The Strasbourg court has held that a breach of Article 14 can be established even where there is no finding of a breach of another Convention right. ${ }^{114}$ However, Article 14 can only be applied where the facts in question falls within the "ambit" of one or more of the other rights of the Convention, that is, when they fall within the range of issues which relate to the enjoyment of the other Convention rights. ${ }^{115}$

Protocol 12 to the Convention is intended to supplement Article 14 with a free-standing guarantee of equality similar to that contained in the Equal Protection Clause of the US Constitution, s.15 of the Canadian Charter of Fundamental Rights and Freedoms, and s.9 of the South African Constitution. ${ }^{116}$ If ratified by the UK, this would open up the possibility of the British courts and the European Court of Human Rights having the ability to hear challenges on equality and non-discrimination grounds across the full range of the British legal system. ${ }^{117}$ However, the UK government has expressed concern about the uncertain impact of Protocol 12 and how it might be applied by the Strasbourg court, and has not as yet either signed or ratified the Protocol. ${ }^{118}$ Pending any future shift in policy, Article 14 with its circumscribed scope and inherent limitations is the only individual equality right incorporated in UK law. For now, it remains the only game in town.

112 Dudgeon v UK (1981) 4 EHRR 149; Smith and Grady v UK (2000) 29 EHRR 493; see also the decision by the European Commission for Human Rights in East African Asians (1981) 3 EHRR 76 that the use of racial or ethnic distinctions could constitute "inhuman and degrading treatment" and therefore violate art.3.

113 See e.g. J. Wadham and H. Mountfield, Blackstone's Guide to The Human Rights Act 1998 (1999), 113: "the incorporation of Article 14 into United Kingdom law is, in itself, unlikely to add much to existing anti-discrimination law."

114 Belgian Linguistic Case (1979-80) 1 EHRR 252. See L. Wildhaber, "Protection Against Discrimination under the European Convention on Human Rights: A Second-class Guarantee?” (2002) 2 Baltic Yearbook of International Law 71.

115 Abdulaziz, Cabales and Balkandali v The United Kingdom (1985) 7 EHRR 471, para.71.

116 For an excellent summary of the Canadian equality jurisprudence, see M. C. Hurley, "Charter Equality Rights: Interpretation of Section 15 in Supreme Court of Canada Decisions", prepared for the Law and Government Division, Parliamentary Research Branch, Canadian Parliament, August 1995, revised February 2004, available at http://www.parl.gc.ca/information/library/PRB pubs/bp402-e.htm_(last accessed 15 November 2005).

117 See U. Khan, "Protocol 12 to the European Convention on Human Rights: A Step Forward or a Step Too Far?" (2001) Public Law 457.

118 For criticism of the UK's reluctance to sign and ratify Protocol 12, see N. Grief, "Non-Discrimination under the European Convention on Human Rights: A Critique of the United Kingdom Government's Refusal to Sign and Ratify Protocol 12" (2002) E.L.Rev 3. 
However, Article 14 has not quite lived down to expectations. It has generated a considerable volume of litigation, and taken with other articles of the Convention it has generated some very significant shifts in English and Scottish law. In particular, cases such as Ghaidan v Mendoza, ${ }^{119}$ Westminster City Council v Morris ${ }^{120}$ and A v Secretary of State for the Home Department $t^{121}$ have seen discriminatory distinctions which were deeply embedded in legislation found to be incompatible with the Convention. The picture however is not all positive. While results have been mixed, it is clear that the courts are still struggling with Article 14, and the case-law that has emerged thus far has again been less than coherent.

Partially, this lack of coherence is the product of the skimpy Strasbourg caselaw on Article 14. The European Court of Human Rights has historically tended to shy away from the complexities of Article 14, preferring instead to base its decisions on other articles of the Convention. ${ }^{122}$ The basics of the Court's approach to Article 14 have been in place since the Belgian Linguistics decision. ${ }^{123}$ However, until recently, the Strasbourg case-law on Article 14 was thin on the ground. The British courts have had to fill in the gaps themselves, but their response has been cautious and perhaps excessively timid: this again perhaps is a reflection of the "under-theorised" nature of equality norms.

While a comprehensive analysis of the Article 14 must await another paper, some of the salient features of the case-law will be highlighted to demonstrate this. In the Court of Appeal decision of Wandsworth $L B C \mathrm{v}$ Michalak, ${ }^{124}$ Brooke L.J. set out a framework for approaching Article 14 issues, framed in terms of a four stage test:

1) Do the facts fall within the ambit of one or more of the Convention rights?

2) Was there a difference in treatment in respect of that right between the complainant on the one hand and others put forward for comparison (the "chosen comparators") on the other?

3) Were the chosen comparators in an analogous situation to the complainant's situation?

4) If so, did the difference in treatment have an objective and reasonable justification. . . ? ${ }^{125}$

119 [2004] UKHL 30.

120 [2005] EWCA Civ. 1184.

121 [2004] UKHL 56.

122 See, e.g. the decision in Lusting-Prean v UK (2000) 29 EHRR 548, where the case was decided on the art. 8 arguments, with the Court finding that the art.14 arguments did not require analysis: see para. 108 .

123 (1979-80) 1 EHRR 252. See also Rasmussen v Denmark (1984), para.38.

124 [2003] 1 WLR 617, 625, para.20.

125 Lord Steyn in $R(S)$ v Chief Constable of South Yorkshire and $R$ (Marper) v Chief Constable of South Yorkshire inserted an extra question between stages two and three: was the difference in treatment based on one or more of the proscribed grounds under art.14? See [2004] UKHL 39, para.42. 
The Michalak test was applied in subsequent Article 14 cases. However, in $R$ v Secretary of State for the Home Department, ex p. Carson, the House of Lords departed from the Michalak test, and adopted a less rigid approach. ${ }^{126}$ This recognised that the question of whether persons could genuinely be said to be in similar positions could be linked to the question of whether the difference of treatment was justified. ${ }^{127}$ The Law Lords went on to state that the use of certain grounds of differentiation, such as race and gender would have to satisfy a very high threshold of justification. The use of other grounds, such as age (the ground at issue in $R \mathrm{v}$ Secretary of State for Work and Pensions, ex parte Reynolds, a case joined with Carson), would face a lower level of scrutiny. ${ }^{128}$

The recognition in Carson that "suspect" forms of classification should face very stiff scrutiny is welcome, and reflects the approach taken by the Law Lords in Ghaidan v Mendoza with regards to distinctions on the basis of sexual orientation. ${ }^{129}$ However, some problems remain. As Baker has argued, the courts in applying Article 14 have tended to let considerations that should go to whether a measure is objectively justified "contaminate" the earlier stage of the test that focuses upon whether persons treated differently are in similar positions, and in contrast are slow to apply the objective justification in its full rigour. This approach can let unchallenged assumptions about the characteristics of individuals and groups seep into the Article 14 analysis. ${ }^{130}$ There has also been a tendency in the case-law to focus on the legislative purpose for the measure in question, as opposed to its actual effects: concentrating just upon the legitimacy of the formal classification used can gloss over its actual impact. ${ }^{131}$

126 [2005] UKHL 37.

127 Brooke L.J. in Michalak had himself described the test as "only a framework", recognised that the different stages of the test could overlap, and emphasised that "there may sometimes. . . be a need for caution about treating the four questions as a series of hurdles, to be surmounted in turn".

128 In Carson itself, a difference of treatment in pension provision, based upon the fact that the applicant was residing outside of the UK, was held to require only a very low level of justification. The Lords considered that wide leeway should be given to public authorities when it came to the use of geographical and other "non-suspect" criteria, especially where social provision is involved. See also $R$ (Hooper) v Secretary of State for Works and Pensions [2005] 1 WLR 1681, where considerable leeway was given to the government in adjusting pension arrangements, even where sex discrimination was involved. See also Secretary of State for Work and Pensions v $M$ [2006] UKHL 11 for similar reasoning.

129 See Lord Nicholls's comments in Ghaidan, [2004] 2 AC 557, especially at para.9. See also the Court of Appeal decision in Secretary of State for Work \& Pensions v $M$ [2004] EWCA Civ. 1343.

130 See A. Baker, "Article 14: A Protector, Not a Prosecutor", in H. Fenwick, G. Phillipson and R. Masterman, Judicial Reasoning and the Human Rights Act 1998 (2006). See also A. McColgan and H. Hill, "The New Equality Bill”, paper prepared for the JUSTICE conference, London, October 2005, p.13.

131 See A. McColgan and H. Hill, "The New Equality Bill", paper prepared for the JUSTICE conference, London, October 2005, p.13. The Court of Appeal decision in $R(A)$ v Secretary of State for the Home Department [2004] QB 335 illustrates this point well: the Court accepted that the formal distinction between nationals and non-nationals was sufficient to justify the difference in treatment, instead of analysing, as the Law Lords did subsequently, whether the effect of the measure 
In contrast, the Strasbourg court in its case-law has shown an increasing readiness to concentrate upon the objective justification stage, and to examine the effects of measures, rather than just the formal classifications used. ${ }^{132}$ Similarly, the Strasbourg court has been much more ready to accept that an issue falls within the ambit of a Convention right than have the British courts. ${ }^{133}$ The HRA case-law has adopted a very restrictive approach to defining the scope of the ambit of Convention rights. ${ }^{134}$ Again, however, recent Strasbourg case-law has adopted a much more generous approach to defining the ambit of Convention rights. In Sidabras and Dziautas v Lithuania, the ECHR considered that the imposition of restrictions upon individuals taking up employment in the private sector could come within the ambit of Article 8, and therefore Article 14 could be triggered. ${ }^{135}$ In the admissibility decision of Stec v UK, the Grand Chamber of the European Court of Human Rights held that non-contributory benefits did come within ambit of Article 1, Protocol 1, contradicting earlier British case-law. ${ }^{136}$ This looser application of the ambit test may actually be eroding the gap that Protocol 12 was intended to fill, and the extent of the gap now in the wake of Sidabras and Stec remains unclear. The British courts are also very restrictive in defining the scope of "other status" grounds under Article 14: again this seems very difficult to reconcile with the Strasbourg jurisprudence. ${ }^{137}$

in singling-out a particular group for discriminatory treatment was justified. See R. Singh, "Equality: The Neglected Virtue" [2004] EHRLR 141-157.

132 See Thlimmenos v Greece (2000) 29 EHRR 162.

133 Partially, this reluctance on the part of the UK courts is due to the vagueness of the ECHR case-law on this point. For example, see the vague attempt to define the ambit of a right in Petrovic v Austria (1998) 4 BHRC 232, para.28: "the subject matter of the disadvantage. . . constitutes one of the modalities of the exercise of a right guaranteed", or the measures complained of are "linked to the exercise of a right guaranteed"'

134 In Association of British Civilian Internees (Far Eastern Region) v Secretary of State for Defence [2003] EWCA Civ.473, the right to property in art.1 of Protocol 1 was given a narrow ambit, a stance that continued to be reflected in subsequent case-law, especially where non-contributory welfare entitlements were concerned. See Lord Hoffmann's views in Carson, para.12, and the agonising of the High Court and Court of Appeal at earlier stages of Carson and Reynolds as to whether either case came within the ambit of art.1, protocol 1. For other examples of restrictive ambit decisions, see also $R$ (Douglas) v North Tynesside $M B C$ [2003] EWCA Civ.1847, Whaley v Lord Advocate [2004] SLT 425, Adams v Scottish Ministers [2003] SLT 366.

135 Mantouvalou has suggested that this decision shows that the Strasbourg court "feels more competent to tackle discrimination". See V. Mantouvalou, "Work and Private Life: Sidabras and Dziautas v Lithuania" (2005) 30(4) ELR 573, 581-82.

136 Application nos. 65731/01 and 65900/01, judgment of $5^{\text {th }}$ September 2005.

137 See the view of Lord Steyn that "other status" grounds should only include forms of distinction that closely resemble or which are closely analogous to the express grounds in art.14 such as race and sex, expressed in $R(S)$ v Chief Constable of South Yorkshire and $R$ (Marper) v Chief Constable of South Yorkshire [2004] UKHL 39, para.48. In Countryside Alliance v Attorney-General [2005] EWHC 1677 Admin., it was held that the singling-out of fox-hunting for prohibition was not discrimination based upon a status that would come within art.14. This appears difficult to reconcile with the more expansive current Strasbourg approach to defining what distinctions can come with "other status": see 
The evolution of the Strasbourg case-law is therefore deviating from the approach adopted by the British courts, by giving freer rein to the transformative potential of Article 14 and being more willing to apply the justification test. ${ }^{138}$ Once again, the expansion of equality and antidiscrimination norms has progressed in fits and starts, and has required extra propulsion from a more expansionist approach adopted by a European court. However, recent decisions, including A and Westminster City Council v Morris, have seen the British courts more willing to apply close scrutiny at the reasonable justification stage to the substantial effects of the measure in question, and to query formal legislative rationales for differences in treatment. In Morris, Sedley L.J. in his rigorous leading judgment adopted an expansive approach to defining the ambit of Article 8, and focussed upon the impact of the measure in question rather than its formal rationale. ${ }^{139}$ In Francis, the Court of Appeal held that "administrative convenience cannot in itself be a sufficient reason for discrimination", again refusing to accept the use of formal classifications that generate discriminatory impact without clear justification. ${ }^{140}$

Again, a gradual fumbling towards a coherent, principled and consistent approach is discernable, which recognises the transformative dimension of rights adjudication. Complexities and uncertainties remain. The extent to which Article 14 will impact upon forms of indirect discrimination remains unclear, as is its potential interpretation in challenges to forms of positive action, the extent of the positive obligations which it imposes, and what horizontal effect may be given to it via the HRA. Other uncertainties also arise with respect to other Convention rights and their potential application in equality and anti-discrimination contexts. For example, the ECHR in Connors v UK recognised that states may be obliged to make special provision for the travelling community to comply with their positive

Chassagnou and Others v France (2000) 29 EHRR 615. See also the very questionable decision by J. Newman in Hopkins v Secretary of State for Defence [2004] EWHC 299 (Admin) that discrimination on the grounds of length of time of cohabiting status was not discrimination on "status" grounds under art.14. See however the more open approach by the Court of Appeal in Francis v Secretary of Sate for Work and Pensions [2005] EWCA Civ. 1303 to what constitutes "personal status".

138 However, see the extremely cautious and poorly reasoned decision in $\mathrm{OH}$ v Czech Republic [2006] ECHR 113 for an indication that the Strasbourg Court also suffers at times from timidity in this area.

139 Rather than becoming embroiled in close analysis of the exact ground of distinction that the legislation in question made use of, Sedley LJ considered that "the attempt to isolate. . . a single ground operative ground of distinction may be a search for a mare's nest", and that it was "more consonant with the purpose of Article 14. . . to address the complex [of factors] itself". See Morris, paras.50-52. He went on to find that the identification of the precise ground for the difference in treatment was not critical, as the lack of firm justification for the legislative provision meant that its discriminatory effect could not be excused, irrespective of the precise differential factor at issue. See paras.35-36. See also the judgment of the Court of Appeal in Secretary of State for Work and Pensions v M [2004] EWCA Civ. 1343, in particular Sedley L.J.'s comments at para.59.

140 Francis v Secretary of State for Work and Pensions [2005] EWCA Civ. 1303. 
obligations to uphold Convention rights: ${ }^{141}$ the Court of Appeal in First Secretary of State v Chichester District Council took a similar approach, ${ }^{142}$ but the Court of Appeal in Price v Leeds has expressed concern that this trajectory the ECHR case-law is incompatible with earlier approaches by the House of Lords. ${ }^{143}$ The decision of the Law Lords in Leeds v Price [2006] UKHL 10 has left some of these issues unresolved. A very interesting question arises as to when the courts may be prepared to find that discrimination constitutes "inhuman and degrading treatment" under Article 3. In $R$ (Gezer) v Secretary of State for the Home Department, the Court of Appeal was unwilling to find a breach by the state of its positive obligation to refrain from exposing individuals to degrading treatment contrary to Article 3, where an asylum-seeker had suffered from severe racial abuse when moved to a Glasgow housing estate as part of the asylum-seeker dispersal programme. ${ }^{144}$

The potential impact of the Act therefore remains uncertain, and it is still bedding-down. There should be no false expectations about the extent of change the Act will bring about. ${ }^{145}$ Rights review rarely advances too far ahead of prevailing social norms and expectations. ${ }^{146}$ However, by opening up new possibilities of challenging discriminatory barriers, the Act imposes pressure upon public authorities to justify the maintenance of these barriers. Exposure to this demand for justification can expose the lack a rational basis or real justification, even when case-law might incline towards complacency. ${ }^{147}$ The existence of the possibility of rights review also forces public bodies (including Parliament) to factor in the possibility of rights

141 [2004] ECHR 223 (27 May 2004). For an analysis of the scope of positive obligations under the ECHR in general, see A. Mowbray, The Development of Positive Obligations under the European Convention on Human Rights by the European Court of Human Rights (2004).

142 [2004] EWCA Civ. 1248. See also Clarke v Secretary of State for the Environment [2001] EWHC Admin 800.

143 [2005] EWCA Civ. 289.

144 [2004] EWCA Civ. 1730. The European Court of Human Rights has recognised that singling out of particular groups on the basis of their racial or ethnic origin can constitute degrading treatment in violation of art.3: see Moldovan v Romania (Application Nos. 41138/98 and 64320/01, unreported, 12 July 2005, East African Asians v UK (1973) 3 EHRR 76.

145 See A. McColgan, "Discrimination Law and the Human Rights Act 1998" in T. Campbell, K.D. Ewing and A. Tomkins (eds.), Sceptical Approaches to Human Rights (2001) 215-241; by the same author, "Women and the Human Rights Act" (2000) 51(3) Northern Ireland Law Quarterly 417; also Women Under The Law: The False Promise of Human Rights (1999).

146 See R. Dahl, 'Decision-Making in a Democracy: The Supreme Court as a National Policy-Maker' (1957) 6 Journal of Public Law 279; see also M. Tushnet, Taking the Constitution Away from the Courts (1999) 153.

147 Many arguments that suggest that rights instruments such as the Human Rights Act are largely incapable of generating meaningful social change are based upon assumptions about the inherent conservatism of the English and Scottish judiciary en bloc, or the limits of adversarial litigation: see, e.g. K. Ewing, "The Futility of the Human Rights Act" (2004) Public Law 829-852. Such accounts however often neglect the positive impact of the shifting legal dynamics that can be triggered by the coming into effect of a rights instrument such as the Human Rights Act. 
review into their thinking, generating a form of "rights orientation" that can yield positive results. ${ }^{148}$ It also opens up new terrain for legal activism, if campaigners employ the language and tools of rights review with an awareness of their limitations and the possibility of backfire. ${ }^{149}$

As with the common law approaches discussed above, the application of the HRA will inevitably fluctuate to a degree, in light of the uncertainty as to the underpinning equality principles. Nevertheless, the HRA is a crucial building block in the establishment of a framework of equality law that can apply to vertical relationships, along with the extension of antidiscrimination legislation to the performance of public functions and the development of the common law equality principle. Taken together with the slow shuffle towards comprehensive anti-discrimination legislation, something approximating a coherent framework of equality and antidiscrimination law is gradually emerging in Britain.

\section{Part Four: Positive Action and the Limits of Anti-Discrimination Legislation}

However, the extent to which this new framework can deliver on the transformative and inclusive ambitions of equality norms remains uncertain. Even a genuinely transformative instrument such as the HRA is limited in its field of application and in what it can achieve. Combined with a coherent anti-discrimination legislative framework and the development of common law equality norms, it may prevent the expression or manifestation of particular forms of prejudice by public authorities. However, it will often be of limited effect in altering underlying structural norms of subordination, as will anti-discrimination legislation in general. ${ }^{150}$

The problem is that institutional forms of exclusion that cannot be readily classified as "discriminatory" tend to slip beneath the radar of equality and anti-discrimination laws. ${ }^{151}$ The findings of the Macpherson Report

148 For this concept of "rights orientation", see C. O'Cinneide, "Democracy and Rights: New Directions in the Human Rights Era" [2004] 57 Current Legal Problems 175-211.

149 See J. Conaghan and S. Millns, "Gender, Sexuality and Human Rights" (2005) 13 Feminist Legal Studies 1-14; S. Millns, "Gender Auditing the Human Rights Act 1998" (2005) 8(1) International Journal of Discrimination and the Law 75-90; S. Palmer, "Feminism and the Promise of Human Rights: Possibilities and Paradoxes" in S. James and S. Palmer (eds.), Visible Women (2002), 92; L. Schwartzman, "Liberal Rights Theory and Social Inequality: A Feminist Critique" (1999) 14 (2) Hypatia 26-47

150 See S. Fredman, Discrimination Law (Oxford, OUP, 2001), 163-168; C. McCrudden, "Anti-Discrimination Goals and the Legal Process" in N. Glazer and K. Young (eds.) Ethnic Pluralism and Public Policy (1983); B. Hepple, "Judging Legal Rights", 33 Current Legal Problems (1983) 71. See also G. Bownes, Snakes and Ladders: Advice and Support for Discrimination Cases in Wales (Cardiff; EOC, 2003). The effect of equality legislation may often be to confine the expression of prejudice within certain tolerated spheres or within 'coded' language, rather than to shift social attitudes.

151 Such practices are often made to appear positively acceptable, as they are outside the legally established definition of discrimination. See N. Lacey, "From Individual to Group", in B. Hepple and E. Szyszczak, Discrimination: The Limits of the Law (1992), pp.102-3. 
demonstrated that even the comparatively well-developed race relations legislative framework was having little impact upon the persistence of forms of "institutional racism" in the Metropolitan Police. ${ }^{152}$ No obligation exists for employers or service providers to take anticipatory action to alter practices and policies that may disadvantage particular groups, with the exception of the reasonable accommodation obligations imposed by the Disability Discrimination Act. This means that structural inequalities and oppressive power relations often remain unchallenged and unaltered.

This could be seen as demonstrating the inevitable limits of what legal norms can achieve by way of social transformation: if structural forms of exclusion are to be broken down, then other forms of policy initiatives will have to be adopted. However, attempts have been made to extend the "classical" framework of equality and anti-discrimination law in an attempt to overcome these limits. In the United States, Owen Fiss, Jack Balkin and others have argued for a shift from an emphasis upon "anti-classification" approaches (i.e. using anti-discrimination law to prohibit any use of discriminatory criteria), to an "anti-subordination" approach, which would place the need to eliminate the "subordinate" status of disadvantaged groups at the centre of equality law. ${ }^{153}$ Fredman has similarly called for the adoption of "fourth generation" positive action approaches, which would make the removal of obstacles to full and equal participation by disadvantaged groups in society one of the central guiding principles of equality law. ${ }^{154}$ In essence, the argument is being made that the transformative aspirations of equality norms need to be directed towards the elimination of forms of group disadvantage. The "social inclusion" approach described by Collins also would involve the adoption of a similar approach.

\section{Mainstreaming and Positive Duties in the Public Sector}

A focus upon social inclusion can be clearly seen in the government's community cohesion strategies and its emphasis upon "outreach" to neglected social groups in education, health and welfare policies. ${ }^{155}$ Mainstreaming has been used in Britain since the early 1990s to encourage the implementation of transformative equality strategies in the public

152 Macpherson et al., The Stephen Lawrence Inquiry (1999).

153 See O. Fiss, "Groups and the Equal Protection Clause", in M. Cohen, T. Nagel and T. Scanlon (eds.) Equality and Preferential Treatment (1977), 85; see also J. Balkin and R. Siegel, "The American Civil Rights Tradition: Anticlassification or Antisubordination?" 58 U. Miami L. Rev 9 (2004).

154 See Fredman, Discrimination Law, pp.14-22, 128-129. See also S Fredman, "Equality: A New Generation?" (2001) 30 ILJ 163; B. Hepple and C. Barnard, "Substantive Equality" (2000) 59 CLJ 566.

155 Interestingly, the argument that government should not as a matter of principle concern itself with this form of social engineering is now rarely made, even by the Conservative Party: in Britain at least, when it comes to issues of state intervention to combat social exclusion, Nozick and Hayek have become cautionary voices counselling against over-enthusiastic state regulation, rather than prophets of an absolutist creed of non-intervention. However, see the comments by Baroness O'Cathain, H.L. Deb., Vol. 674, col. 779, 9 November 2005, citing the Bishop of Winchester. 
sector. $^{156}$ However, the effectiveness of mainstreaming mechanisms has proved mixed: positive developments in Scotland and Wales have not always been paralleled in England. ${ }^{157}$ A major problem with mainstreaming policies is that they are "soft law" initiatives: as mainstreaming initiatives are not legally enforceable duties, implementation of effective mainstreaming is usually dependant upon political good-will, organisational capacity, sustained leadership and expert advice. ${ }^{158}$ In the absence of this, initiatives tend to be at the best procedure-orientated, and at the worst lapse completely, a problem exacerbated by the lack of clarity as to what equality principles should ultimately be applied. ${ }^{159}$

These defects have resulted in a series of attempts to beef up monitoring procedures for ensuring compliance with mainstreaming guidelines. At EU level, the provision of structural funds is linked to evidence of gender mainstreaming, while the Scottish Parliament and Welsh Assembly have introduced parliamentary scrutiny of how mainstreaming is being implemented in practice. Similar measures have been lacking in England and at Westminster level. ${ }^{160}$ Nott has argued that the lack of any clear role for the new CEHR in promoting effective mainstreaming represents a serious wasted opportunity. ${ }^{161}$ Despite its considerable promise, mainstreaming has only really taken root in Wales and Scotland, where fertile political soil exists for it to put down roots: in the perhaps more hostile political climate of England, results have been less good. ${ }^{162}$

This has prompted the introduction of a series of legally binding positive duties upon public authorities since 1998. Following the introduction in that year of the section 75 positive equality duty in Northern Ireland, less intense versions of this duty were imposed upon the Welsh Assembly and Greater London Assembly. ${ }^{163}$ In the wake of the Macpherson Report, and following

156 See M. Pollack and E. Hafner-Burton, "Mainstreaming Gender in the European Union" (2000) 7 Journal of European Public Policy 3, 432-457; T. Rees, Mainstreaming Equality in the European Union (1998); S. Nott, "Mainstreaming Equal Opportunities: Succeeding Where All Else Has Failed?" in A. Morris and T. O'Donnell (eds.) Feminist Perspectives on Employment Law (1999) 203.

157 See S. Nott, "Securing Mainstreaming in a Hostile Political Environment" [2005] 8(1) International Journal of Discrimination and the Law 121.

158 See the conclusions reached in a recent National Audit Office report: National Audit Office, Delivering Public Services to a Diverse Society (2004). See also G. Mills, "Combating Institutional Racism in the Public Sector" (2002) 31 ILJ 9698. Maria Stratigaki has argued that at the level of the EU institutions, the adoption of mainstreaming measures is often used to neutralise or defer the adoption of other forms of positive action measures. See M. Stratigaki, "Gender Mainstreaming Vs Positive Action" (DATE) 12(2) European Journal of Women's Studies 165-186.

159 J. Rubery et al, "The Ups and Downs of European Gender Equality Policy", (2004) 35 Industrial Relations Journal 603. See also F. Mackay and K. Bilton, Learning From Experience: Lessons in Mainstreaming Equal Opportunities (2003).

160 See S. Nott, ibid.

161 See S. Nott, "Securing Mainstreaming in a Hostile Political Environment".

162 ibid.

163 These duties are much more vague in content than the Northern Irish duty, and lack any real enforcement mechanism aside from judicial review: however, as they have again fallen on fertile political soil, these duties have had some impact, 
political pressure from the CRE and ethnic minority organisations, a much stronger positive race equality duty was imposed on listed public authorities in the Race Relations (Amendment) Act 2000. This considerably extended the largely ineffective duty originally imposed upon local authorities by s. 71 of the Race Relations Act $1976 .{ }^{164}$ A disability duty has been imposed upon public authorities in general (defined in a similar manner as in the Human Rights Act) in the Disability Discrimination Act 2005, while a positive duty for the gender ground is to be introduced in the Equality Bill 2005. ${ }^{165}$ The Scottish Parliament, having a power under Schedule 5 of the Scotland Act 1998 to encourage equal opportunities, has imposed duties on several types of devolved authorities. ${ }^{166}$

Positive duties impose a statutory duty on public authorities to give "due regard" to eliminating unlawful discrimination, and to promoting equality of opportunity in the performance of their functions. To supplement these general duties, additional specific duties are also imposed by statutory instruments introduced by the relevant Secretary of State. ${ }^{167}$ At present, these specific duties can be enforced by the relevant equality commissions, who are given special investigatory and enforcement powers to issue compliance notices. The CEHR is to be given extended powers to investigate and enforce compliance with both the general and the specific duties. ${ }^{168}$ The introduction of positive duties is therefore an ambitious attempt to make equality issues a core concern for public authorities, and through this to encourage the transformation of existing practices. ${ }^{169}$

in particular the Welsh duty: see P. Chaney and R. Fevre, An Absolute Duty: Equal Opportunities and the National Assembly for Wales (2002).

164 See C. McCrudden, "Equality and Non-Discrimination", paras.11.189-11.191, pp.663-4.

165 See C. O’Cinneide, “Positive Duties and Gender Equality" [2005] 8(1) International Journal of Discrimination and the Law 91-119; by the same author, "A New Generation of Equality Legislation? Positive Duties and Disability Rights", in A. Lawson and C. Gooding (eds.), Disability Rights in Europe (2005) 219-247.

166 See C. O'Cinneide, Taking Equal Opportunities Seriously: The Extension of Positive Duties to Promote Equality (2003), Part V.

167 These specific duties impose obligations upon public authorities to formulate and publicise their methods of complying with the duty, and to collect the necessary data by means of consultation and monitoring to enable them to assess the "equality impact" of their policies and practices.

168 Audit bodies, such as the Audit Commission, the public sector inspectorates and other regulatory agencies, are also expected to monitor how both the general and specific duties are being implemented, and judicial review can also be used to enforce compliance.

169 Some of the tools of "new public management", such as auditing mechanisms, monitoring requirements, and a steering duty, are combined together with neorepublican and democratic-participative aspirations within the positive duty mechanism. See O'Cinneide, "Positive Duties and Gender Equality". The potential impact of these duties has lead to calls for their scope to be extended beyond the equality context to the full range of human rights. See G. McKeever and F. Ni Aoláin, "Thinking Globally, Acting Locally: Enforcing SocioEconomic Rights in Northern Ireland" [2004] EHRLR 158. For a more sceptical perspective, see C. McCrudden, "Mainstreaming Human Rights", in C. Harvey (ed.) Human Rights in the Community: Rights as Agents for Change (2005). 
The duties are however limited in certain important respects. The duties are supposed to "steer" how other duties and functions are performed: equality concerns are to be given their due proportionate weight in decisionmaking. ${ }^{170}$ However, this by itself gives little guidance as to how important promoting equality of opportunity should be, or when equality considerations can be overridden by other policy considerations, or what constitutes promoting equality of opportunity in the first place. ${ }^{171}$ There is also a danger that public authorities may relapse into formal equality approaches, or leveldown the delivery of public services in response to an identification of adverse impact. ${ }^{172}$ Once again, the lack of underlying agreement on what equality principles should govern public policy generates an inevitable lack of clarity: positive duties may encourage an analysis of what steps should be taken to promote equality, but do not specify what vision of equality should be applied, leaving the door open to public authorities to apply the vision they choose to prioritise.

Adherence to the duties could also just take the form of "process compliance", where authorities treat the duty as merely involving complying with a set of bureaucratic "tick-box" requirements. Verloo has suggested that mainstreaming has to "resonate" with the existing assumptions, rhetoric and practices within which public authorities work. ${ }^{773}$ This could equally also apply to positive duties. There is therefore a danger that the duties may become no more than a technocratic tool in policymaking, which can be readily co-opted to maintain existing practices. ${ }^{174}$ Their transformative potential may thus prove to be nominal. Nott has also suggested that the duties can be interpreted as only requiring an initial consideration of what policies are directly relevant to equality concerns, and an assessment of the impact of those policies alone. In contrast, a full mainstreaming approach would require equality considerations to be built into all policies. ${ }^{175}$

170 Fredman, Discrimination Law, 180.

171 In an important judgment in $R$ (Elias) v Secretary of State for Defence [2005] IRLR 788, Elias J. held that a failure to consider whether a particular policy raised issues relating to racial equality, or to assess whether any adverse impact was possible, or to consider what steps might be necessary to eliminate any negative impact, would breach the duty. This gives some "teeth" to the duty, but does not clarify how an authority is to balance competing considerations.

172 See O'Cinneide, "Positive Duties and Gender Equality", 104.

173 M. Verloo, "Another Velvet Revolution? Gender Mainstreaming and the Politics of Implementation", IWM Working Paper, No.5/2001 (2001), 9-10; available at: http://www.iwm.at/publ-wp/wp-01-05.pdf (last accessed 5 October 2005).

174 See also N. Lacey, "Legislation Against Sex Discrimination: Questions from a Feminist Perspective" (1987) 14 Journal of Law and Society 411-21. Maria Stratigaki has argued that at the level of the EU institutions, the adoption of mainstreaming measures is often used to neutralise or defer the adoption of other forms of positive action measures. See M. Stratigaki, "Gender Mainstreaming Vs Positive Action”, 12(2) European Journal of Women's Studies 165-186.

175 See S. Nott, "Securing Mainstreaming in a Hostile Political Environment", pp.126-130. Nott cites the Department of Trade and Industry's race equality scheme as adopting this narrow filtering approach to the duty. She also highlights the weakness of the enforcement mechanisms for the duty: see also O'Cinneide, "Positive Duties and Gender Equality", pp.104-06. Elias J. in Elias appeared to accept that the duty to promote equality of opportunity only applied to policies that were directly related to equality and anti-discrimination concerns, confirming 
The duties are therefore far from being an ideal mechanism for ensuring the adoption of anti-subordination approaches on the part of public authorities. However, their existence enables the equality commissions to investigate the failure of public authorities to take positive steps to eliminate discrimination and promote equality of opportunity. ${ }^{176}$ In addition, the duties have considerable symbolic and educative potential. The duty mechanism recognises that unconscious, structural or institutional forms of discrimination exist, and that it is a core responsibility of public authorities to take steps to minimise these forms of inequalities. ${ }^{177}$ They also can serve as useful "pressure points" to demand greater focus upon equality issues from public authorities: authorities can be called to account for how they have complied with the duty, and pressed to demonstrate progress.

The existence of the duty can also enable public authorities to take proactive measures designed to promote equality of opportunity. In the past, the absence of a specific duty to promote equality of opportunity has meant that public authorities have often lacked a clear statutory authority for implementing equality policies. ${ }^{178}$ The introduction of positive duties now partially overcomes this problem. The duties will also have an impact upon how authorities perform other statutory duties: they can justify the placing of considerable weight on equality considerations in deciding how to perform other duties and functions. ${ }^{179}$ The duties can thus both serve to steer and to

Nott's fears. The intent and wording of the duties does not necessarily support this approach: however, in the absence of real clarity as to what the duties require, Elias J.'s obiter opinion illustrates the risk that the scope of the duties will be interpreted and applied narrowly.

176 The important decision of the Northern Ireland High Court in The Matter of an Application by Peter Neill for Judicial Review [2005] NIQB 66 confirmed that the Equality Commission for Northern Ireland (ECNI) had the power under its investigatory function conferred by the $\mathrm{s} .75$ duty to find that the positive equality duty had not been sufficiently complied with by the Northern Ireland Office in considering the equality impact of its decision to extend the legislation permitting the issuing of ASBO orders to Northern Ireland. The powers of the British equality commissions and the CEHR in respect of the British duties are similar to that of the ECNI, so this decision should also confirm the ability of the British commissions to make similar findings.

177 The existence of a duty may also serve to compel authorities to adopt equality initiatives even where the perception exists that inequality is no longer a "real problem": for the dangers associated with this perception, see D. Rhode, "The 'No-Problem' Problem: Feminist Challenges and Cultural Change" (1991) 100 Yale LJ 1731.

178 See P. E. Morris, "Legal Regulation of Contract Compliance: An AngloAmerican Comparison" (1991) 19 Anglo-American Law Review 87-144, especially at $93-103$. The s.71 duty on local authorities to promote race equality, while limited in impact, did give local authorities some legal basis for funding race equality councils and some scope for the insertion of race equality clauses into procurement contracts: ibid., 93-121. However, the extent and enabling impact of this remained very uncertain: see Wheeler v Leicester City Council [1985] 1 A.C. 1054 and $R$ v Lewisham L.B.C., ex parte Shell (U.K.) Ltd. [1988] 1 All ER 938.

179 For an interesting example of the possible impact of the duty, see the Local Government Information Unit (LGiU) briefing, Election Meetings: Use of School and Community Premises (London: LGiU, 29 $9^{\text {th }}$ March 2004), and CRE, Elections and the Duty to Promote Race Equality (2004). However, note that the L. Gill 
enable public authorities to adopt policies based upon concepts of substantive equality, even if they cannot dictate with any real precision the exact contents of these policies. Therefore, the duties may have genuine potential as transformative instruments, despite their uncertain scope and inherent limitations. ${ }^{180}$

However, the introduction of a comprehensive scheme of positive duties will not be enough in itself to establish an adequate equality and antidiscrimination framework for the British public sector. Positive duties can orient how public authorities exercise their powers and functions within the existing statutory framework, but cannot overcome or modify statutory restrictions on what public authorities can do, or resolve debates about core issues of principle. Finally, their effect is confined to the public sector: the shrinking sphere of public authority activity means that the impact of the duties is confined to this narrowing sphere. ${ }^{181}$

\section{Transformation and the Private Sector}

Taking measures to combat disadvantage could be required in the private sector. The Hepple Report recommended that positive duties be imposed upon employers to take measures to promote equality of opportunity in their employment practices. ${ }^{182}$ The employment equity legislation in Northern Ireland imposes similar obligations upon private sector employers, and has had reasonable success. ${ }^{183}$ Similar measures in Canada have also generated some useful results. ${ }^{184}$ The imposition of such positive duties in the private

has altered its guidance on the impact of the duty: see L. Gill, Guidance Update use of Public Premises at Election Time (2005).

180 The Northern Irish equality duty does extend across the full range of equality grounds. Certain complexities exist in framing such cross-ground duties, but these are not insurmountable with careful design, and therefore a set of cross-ground duties could also be introduced in Britain. See O'Cinneide, Taking Equality of Opportunity Seriously, Part V.

181 However, the duties apply to all functions of public authorities, including those that they choose to contract out: the responsibility for complying with the duty requirements remains with the authority, which means that the duties may have some impact even in areas marked by extensive contracting-out of service delivery and other functions. See O'Cinneide, Taking Equal Opportunities Seriously, Part V See also CRE, Statutory Code of Practice on the Duty to Promote Race Equality (2002).

182 The Report suggested that employers should be required to undertake a three-year periodic review of employment procedures, and, in the event of the discovery of significant under-representation of particular groups, obligated to take reasonable remedial action by means of an employment equity plan. See the Hepple Report, para.3.37. Employers with 10 or more employees would also be required to carry out a similar three-yearly periodic pay audit and take appropriate action via a pay equity scheme where discrepancies were identified. See paras.3.41-3.50.

183 See C. McCrudden, R. Ford, A. Heath, "Legal Regulation of Affirmative Action in Northern Ireland: An Empirical Assessment" (2004) 24 (3) OJLS 363-415.

184 See the Canadian Employment Equity Act 1986, revised and extended in late 1995, and at provincial level, the Ontario Equal Pay Act 1987 and the Quebec Act Respecting Equal Access to Employment in Public Bodies 2000, c.45, s.1 Moderate gains have been identified from the implementation of these positive duties, which have been criticised as lacking adequate breath of application and a sufficiently rigorous set of enforcement mechanisms. See C. Agocs, "Canada's 
sector could play a role in breaking down structural forms of discrimination, if adequate enforcement is introduced with due respect for the need to avoid excess bureaucracy. ${ }^{185}$ Another possible reform could involve the introduction of a cross-ground set of "reasonable accommodation" requirements into British anti-discrimination law. Disability discrimination legislation imposes an obligation to take special measures to facilitate the needs of disabled persons in accessing services and in employment: this legislative obligation to take positive measures is capable of being transplanted to other equality grounds. ${ }^{186}$ Contract compliance mechanisms, whereby public authorities require contractors to introduce rigorous equal opportunity policies, could also be very effective tools. ${ }^{187}$

However, the use of such incentives and requirements has not found favour with the UK government, outside of the Northern Irish context. ${ }^{188}$ Pragmatic concerns about the excessive costs of business regulation have meant that no attempt has been made as yet to introduce private sector duties or general reasonable accommodation requirements in Britain. Indeed, the use of contract compliance policies by public authorities has been reined in and positively discouraged. Part 11 of the Local Government Act 1988 Act restricted or eliminated the ability of local authorities to use contract compliance measures outside of the race equality context. ${ }^{189}$ Even the

Employment Equity Legislation and Policy, 1986-2000: Unfulfilled Promises", in C. Agocs (ed.) Workplace Equality: International Perspectives on Legislation, Policy and Practice (2003), Ch. 4. See also A. McColgan, "Equal Pay: Lessons from Ontario's Pay Equity Unit", Working Paper No 5, Independent Review of the Enforcement of UK Anti-Discrimination Legislation, November 1999. For the application of similar approaches in Scandinavia, see K. Mile, "Mainstreaming Equality - Models for a Statutory Duty", in Mainstreaming Equality: Models for a Statutory Duty - Conference Report (Dublin: Equality Authority, 2003), available at www.equality.ie.

185 See C. O'Cinneide, Taking Equal Opportunities Seriously: The Extension of Positive Duties to Promote Equality (2003), Part 7.

186 Canadian anti-discrimination legislation, for example, extends the requirement to make "reasonable accommodation" across all the recognised equality grounds. For the Canadian approach, see British Columbia (Public Service Employee Relations Comm.) v B.C.G.E.U. (1999) 35 C.H.R.R. D/257 and British Columbia (Superintendent of Motor Vehicles) v British Columbia (Council of Human Rights) (1999), 36 C.H.R.R. D/129; Central Okanagan School Dist. No. 23 v Renaud (1992), 16 C.H.R.R. D/425 (S.C.C.).

187 See C. McCrudden, "Using Public Procurement to Achieve Social Outcomes" (2004) 28(4) Natural Resources Forum 257-267.

188 Northern Ireland, as in may other areas of equality policy, is seen as an exceptional case.

189 See P.E. Morris, "Legal Regulation of Contract Compliance: An Anglo-American Comparison", 103-121; C. McCrudden, "Codes in a Cold Climate" (1988) 51 $M L R$ 409. Despite the potentially greater scope for equality-based measures opened up by the Helsinki Concordia Bus decision (Case 513-99, [2002] ECR I7213), and the recent legislative package clarifying the scope for social considerations available in public procurement (Directives 2004/17/EC and 2004/18/EC), EC legislation in this area has also consistently lacked real clarity as to when the introduction of such contract compliance requirements are compatible with EC law. See C. Tobler, "Encore: 'Women's Clauses' in Public Procurement under Community Law" [2000] 25(6) European Law Review 618631; the Hepple Report, paras.3.71-3.73, pp.83-84. 
marginal loosening of these controls with the introduction of the "Best Value" contracting regime in 2000 has not deterred the "chilling effect" such controls have exercised upon the use of contract compliance by public authorities. ${ }^{190}$ The positive duties may be able to open some additional chinks in these regulatory constraints on the use of contract compliance. However, an effective framework for the use of contract compliance can only be put into place if the existing statutory restrictions are removed or comprehensively reformed: tinkering at the edges can only go so far.

It remains to be seen whether the Discrimination Law Review being conducted at present by the Women and Equality Unit will make any recommendation on this point, or on the introduction of other forms of positive requirements upon private employers. When it comes to this issue, liberal autonomy principles, neo-liberal free market approaches and real pragmatic concerns about bureaucratic load clash with the transformative ambitions of substantive equality theory: the underlying lack of social consensus as to what principles should prevail, and how far the transformative aspirations of equality norms should be pushed, hampers any easy resolution of this tension.

\section{Preferential Treatment and the Limits on Positive Action}

It is also worth noting that the current framework of equality and antidiscrimination law actually places obstacles in the way of the development of some anti-subordination approaches. The controls on the use of contract compliance mechanisms have already been discussed. In addition, many private and public sector organisations have in recent years adopted various forms of diversity management strategies. Such strategies aim to ensure a more "diverse" workforce, and are intended to mainstream good diversity practice into business decision-making and practices, and in particular into human resources policy. ${ }^{191}$ They make use of a range of positive action strategies, which are designed to encourage more applicants for employment or promotion from under-represented groups. ${ }^{192}$ However, as Barmes and Ashtiany have argued, many of these strategies exist in a legal grey zone. ${ }^{193}$

British anti-discrimination statutes tend to adopt a symmetrical and formal model of equality. ${ }^{194}$ The "but for" test adopted by the House of Lords in Eastleigh BC $\mathrm{v}$ James ${ }^{195}$ to determine if direct discrimination has taken place does not involve an analysis of whether disadvantage or a denial of dignity is

190 See the comprehensive analysis in A. McColgan, Discrimination Law ( $2^{\text {nd }}$ ed.) 386-407.

191 See R. Thomas, "From Affirmative Action to Affirming Diversity" (1990) 68 Harvard Business Review 107-117.

192 For a discussion of the strengths and problems of "diversity management" strategies, see L. Barmes with S. Ashtiany, "The Diversity Approach to Achieving Equality: Potential and Pitfalls" (2003) 32 Industrial Law Journal 274-96; J. Wrench, "Diversity Management Can Be Bad For You" (2005) 46(3)

193 ibid.

194 See Fredman, Discrimination Law, 130-135.

195 [1990] 2 AC 751. 
underpinning the act of differentiation. ${ }^{196}$ Preferential treatment will therefore fall foul of anti-discrimination controls, unless it comes within a statutory exception. However, very few exceptions have been permitted. The ones that do exist have been given narrow interpretations by courts and tribunals, and appear to be very circumscribed in scope. ${ }^{197}$ In particular, the scope of the "training" and "encouragement" positive action exceptions in the existing legislation is not clear.

Article 7 of the Framework Equality Directive allows Member States to adopt measures to prevent or compensate for disadvantages linked to any of the grounds covered by the Directive. ${ }^{198}$ However, in implementing these Directives, the government elected not to take advantage of this permitted scope for positive action. ${ }^{199}$ The major exception is the Disability Discrimination Act, which does not adopt a symmetrical model of equality and permits preferential treatment for disabled persons. ${ }^{200}$ However, with this and the other narrow exceptions, forms of preferential treatment that fall outside the scope of the statutory exceptions will constitute direct discrimination and therefore are illegal. ${ }^{201}$

Therefore, any diversity programmes that could be interpreted as benefiting a member of a disadvantaged group may run the risk of falling outside the scope of these exceptions, and therefore of being in violation of the legislation. ${ }^{202}$ Barmes suggest that this uncertainty generates a "chilling

196 See $A C A S$ v Taylor EAT/788/97. Lizzie Barmes has argued that recent decisions may have begun to adopt a greater focus on the intent behind the use of suspect classifications, and therefore that there may be a move away from the strict application of the James "but for" test. However, as she notes, this trend is not clear, and may be confined to victimisation cases. See L. Barmes, "Promoting Diversity and the Definition of Direct Discrimination" (2003) 32(3) ILJ 200.

197 See e.g. Hughes v Hackney LBC, Employment Tribunal 6 Feb 1986, unreported; Lambeth L.B.C. v Commission for Racial Equality [1990] IRLR 231. See H. Slater, "Making a Positive Difference: A Legal Guide to Positive Action" (2002) 111 Equal Opportunities Review, November 2002, 12-17; A. McColgan, 148157.

198 Art.5 of the Race Directive contains a similar provision.

199 See Equality and Diversity: Coming Of Age (2005), Part 4.2. The draft Age Regulations make provision for exceptions for training and encouragement of under-represented age groups, similar to the narrow exceptions contained in the SDA and RRA.

200 See S. Fredman, "Disability Equality: A Challenge the Existing AntiDiscrimination Paradigm?" in A. Lawson and C. Gooding, Disability Rights in Europe (2005) 199-218.

201 Age is an exception. A general defence of objective justification is available for any kind of direct age discrimination. This means that many forms of positive action may be justified without having to come within this narrow positive action exception in the draft regulations: see Equality and Diversity: Coming Of Age (2005), para.4.2.6.

202 See L. Barmes, "Promoting Diversity and the Definition of Direct Discrimination" (2003) 32 (3) ILJ 200. Similar problems apply in Ireland: see C. Costello, "Positive Action", in C. Costello and E. Barry (eds.) Equality in Diversity: The New Equality Directives (2003) 177-212, especially at 199-206. 
effect" that can deter the use of such diversity strategies. ${ }^{203}$ It is certainly true that any attempts to use any form of preferential treatment to compensate for disadvantage or to create a "critical mass" of employees or managers from under-represented groups will fall foul of the legislation. So do will the use by public authorities of even minor forms of preferential treatment designed to enhance equality of opportunity, notwithstanding the existence of the positive public sector duties.

Fiss, Fredman, Elizabeth Anderson and others have argued that combating the disadvantages faced by particular social groups may require special and even preferential treatment of these groups in appropriate circumstances. ${ }^{204}$ They argue that the current restrictions are incoherent, as they deprive policymakers of a potentially valuable tool for addressing group disadvantage. ${ }^{205}$ In contrast, opponents and sceptics suggest that it is more consistent with the general thrust of anti-discrimination legislation to restrict its use. ${ }^{206}$ In general, successive UK governments have adopted this second viewpoint and set their face against the use of preferential treatment in Britain. ${ }^{207}$

The difficulty with this approach is that while in the abstract, it may be possible to distinguish preferential treatment from other types of positive action, this is increasingly proving difficult to do in practice, given the range of diversity strategies that are now commonplace. There is an uncertain borderline between preferential treatment and strong encouragement for

203 Barmes, ibid. The CRE has been obliged recently to offer more guidance for employers in this area: see R. Karim, "Take Care When Being Positive", Connections, Winter 2004.

204 See O. Fiss, "Groups and the Equal Protection Clause"; see also J. Balkin and R. Siegel, "The American Civil Rights Tradition: Anticlassification or Antisubordination?", E. S. Anderson, "Integration, Affirmative Action and Strict Scrutiny" (2002) NYUL Rev 1195; S. Fredman, "Reversing Discrimination" (1997) 113 LQR 575; B. Parekh, "A Case for Positive Discrimination", in B. Hepple and E. Szyszczak (eds.) Discrimination: The Limits of the Law (1992); R. Dworkin, A Matter of Principle (1985); G. Ezorsky, Racism and Justice: The Case for Affirmative Action (1991).

205 Trevor Phillips, chair of the CRE, has called for the suspension of restrictions on preferential treatment to ensure that more ethnic minority recruits join the police: see P. Butler and S. Salman, "Police "Should Favour Black Recruits", The Guardian: Society, March $17^{\text {th }} 2004$. There were media reports that the UK government was toying with this suggestion: see BBC News, "Police Plan to Boost Ethnic Ranks", available at http://news.bbc.co.uk/2/hi/uk_news/ 3634085.stm (accessed 15 November 2005). See also S. Fredman, "Reversing Discrimination" (1997) 113 LQR 575; B. Parekh, "A Case for Positive Discrimination", in B. Hepple and E. Szyszczak (eds.) Discrimination: The Limits of the Law (1992).

206 See e.g. T. Eastland, Ending Affirmative Action: The Case for Colorblind Justice (1996).

207 In contrast, successive UK governments have been less concerned about the use of forms of preferential treatment in Northern Ireland, such as the introduction of the "Patten quota" for recruitment to the Police Service for Northern Ireland, and the leeway given to positive action to address group under-representation by the employment equity legislation. Again, Northern Ireland is seen as a "special case". See A New Beginning: Policing in Northern Ireland, The Report of the Independent Commission on Policing for Northern Ireland (1999). 
disadvantaged groups, and the law at present is not providing clear or coherent boundary lines. There is also a clear lack of clear principle underlying the current set of exceptions, and an overall lack of clarity in the legislation. For example, the Sex Discrimination (Election Candidates) Act 2002 permits political parties to take positive action, including the use of preferential treatment, to reduce inequalities on the grounds of gender in candidate numbers. ${ }^{208}$ The introduction of this exception has not been followed by other new exceptions. But why is preferential treatment permissible in selecting political candidates and not in other areas? The answer is not apparent. Greater clarity and coherence are required, and some loosening-up of the current restrictions on the use of preferential treatment (and thereby other forms of positive action) should again be on the agenda of the Discrimination Law Review. ${ }^{209}$

However, once again, the absence of clear agreement on core principles means that the transformative aspirations of substantive equality approaches come into conflict with other concepts, and this generates a lack of coherence. As discussed above, a strong argument can be made that a "best" understanding of equality norms suggest that they should be seen as focusing upon eliminating certain types of harm and transforming social structures in line with an overall aspiration towards equality of respect. An overemphasis on avoiding suspect classification at the expense of these two goals appears to be incompatible with this best understanding. However, British law remains slow to nail its colours to the anti-subordination mast.

Another set of issues remains unresolved. Anti-subordination approaches are primarily concerned with addressing group disadvantage and transforming social practices. However, they also go further than other equality norms, because they require positive action to be taken towards achieving a goal of equality of respect or status, rather than just requiring avoidance of particular forms of action. But how to measure the extent to which different groups are denied equality of respect, and how to define what this term means? Should public authorities aim to secure equality of outcome across different social groups, or seek to achieve alternative goals? ${ }^{210}$ Is there a danger that other

208 See C. O'Cinneide and M. Russell, "Positive Action to Promote Women in Politics Some European Comparisons" (2003) ICLQ 587-614.

209 Even if British law is clarified, the case-law of the European Court of Justice on positive action may still generate uncertainty. It is still not clear how much freedom the ECJ will permit to member states in using special measures to combat disadvantages across the different equality grounds. However, at present, EC law is more permissible and flexible than British law when it comes to positive action: see C. Costello, "Positive Action", in C. Costello and E. Barry (eds.) Equality in Diversity: The New Equality Directives (2003), 177-212; C. Tobler, "Positive Action under the Revised Second Equal Treatment Directive", in AFFA and EWLA (ed.) L'égalité entre femmes et hommes et la vie profesionnelle; Le point sur les développements actuels en Europe (2003) 59-92.

210 For interesting analysis of the question of the legitimacy of utilising equality of outcome as the appropriate goal in such circumstances, see A. Phillips, "Defending Equality of Outcome" (2004) 12 (1) Journal of Political Philosophy 1. See also A. Phillips, Which Equalities Matter? (1999); E. Anderson, "What is the Point of Equality?" (1999) 109 Ethics 287-338; I. Marion Young, "Equality of Whom?" (2001) 9 Journal of Political Philosophy 1-18. However, is equality of outcome actually a fair test? Is it true that all groups should perform in an 
forms of disadvantage such as socio-economic status will be overlooked in the focus upon race, gender, disability and the other grounds of disadvantage recognised in the anti-discrimination legislation? Does positive action serve to reinforce divisive group identities and perpetuate inter-group tensions? Does it encourage claims of victim status, engendering a cycle of assertions of group disadvantage that can become self-fulfilling prophecies? The makings of a coherent framework of equality and anti-discrimination law is in place in Britain, but how and whether to expand its scope to encompass anti-subordination approaches requires a real engagement with the currently under-theorised principle of "equality", and how far should the transformative dimension of equality norms be extended.

\section{Conclusion}

British equality and anti-discrimination law has undergone a considerable expansion in recent years. Anti-discrimination protection has been considerably extended, and may be extended further. Considerable shifts have occurred in judicial approaches to equality issues, the Human Rights Act has come into force, and a single Commission for Equality and Human Rights will be established. The foundations of a truly coherent framework are being put into place, even if British law is still fumbling, confusing and being slowly dragged by European influences towards its completion. If and when completed, this framework should provide consistent protection against unequal treatment in both horizontal and vertical relationships, and provide suitable avenues for legal challenges to be made against barriers to equal treatment and group inclusion. It will even give some effect to the transformative ambitions inherent in equality and anti-discrimination norms, in particular via the "constitutionalising" of equality as a fundamental common law norm and through the protection offered by the Human Rights Act.

However, the transformative potential of this new framework is finite and limited. To give it full effect, anti-subordination approaches may need to be adopted. However, the use of such approaches has not been constitutionalised or embedded in legislation, beyond the introduction of the public sector positive duties. Serious debates remain to be had about how far should the transformative dimension of equality norms be applied, and how other values like the neo-liberal attachment to freeing up market outcomes should be reconciled with these transformative aspirations. Other questions remain: how as what space should be given to assertions of religious identity, or what weight should be given to private autonomy as distinct from public engagement.

"Equality" remains an under-theorised concept in Britain: there is sufficient agreement to ensure the gradual development of a coherent framework of laws, but there is little agreement on fundamental principles, nor on how this framework should be stretched and applied in several cases. The comparatively well-developed equality and anti-discrimination legal regimes

equivalent manner in an "equal" society, irrespective of different group cultural norms and expectations? This is contestable: and yet, the use of equality of outcomes as a tool of assessing progress in the implementation of the positive duties has become commonplace. 
Fumbling Towards Coherence: The Slow Evolution of Equality... 101

of Canada and South Africa have their roots in widespread political and social consensus as to the appropriate approaches to equality issues that should be adopted in law and policy. However, that degree of conceptual agreement is lacking in Britain, and therefore equality and antidiscrimination law is still fumbling towards coherence. 